Review

\title{
Functional Role of Non-Coding RNAs during Epithelial-To-Mesenchymal Transition
}

\author{
Almudena Expósito-Villén, Amelia E. Aránega and Diego Franco * (iD \\ Cardiovascular Development Group, Department of Experimental Biology, University of Jaén, 23071 Jaén, Spain; \\ aev00006@red.ujaen.es (A.E.-V.); aaranega@ujaen.es (A.E.A.) \\ * Correspondence: dfranco@ujaen.es; Tel.: +34-953-212-763
}

Received: 28 March 2018; Accepted: 23 May 2018; Published: 28 May 2018

\begin{abstract}
Epithelial-to-mesenchymal transition (EMT) is a key biological process involved in a multitude of developmental and pathological events. It is characterized by the progressive loss of cell-to-cell contacts and actin cytoskeletal rearrangements, leading to filopodia formation and the progressive up-regulation of a mesenchymal gene expression pattern enabling cell migration. Epithelial-to-mesenchymal transition is already observed in early embryonic stages such as gastrulation, when the epiblast undergoes an EMT process and therefore leads to the formation of the third embryonic layer, the mesoderm. Epithelial-to-mesenchymal transition is pivotal in multiple embryonic processes, such as for example during cardiovascular system development, as valve primordia are formed and the cardiac jelly is progressively invaded by endocardium-derived mesenchyme or as the external cardiac cell layer is established, i.e., the epicardium and cells detached migrate into the embryonic myocardial to form the cardiac fibrous skeleton and the coronary vasculature. Strikingly, the most important biological event in which EMT is pivotal is cancer development and metastasis. Over the last years, understanding of the transcriptional regulatory networks involved in EMT has greatly advanced. Several transcriptional factors such as Snail, Slug, Twist, Zeb1 and Zeb2 have been reported to play fundamental roles in EMT, leading in most cases to transcriptional repression of cell-cell interacting proteins such as ZO-1 and cadherins and activation of cytoskeletal markers such as vimentin. In recent years, a fundamental role for non-coding RNAs, particularly microRNAs and more recently long non-coding RNAs, has been identified in normal tissue development and homeostasis as well as in several oncogenic processes. In this study, we will provide a state-of-the-art review of the functional roles of non-coding RNAs, particularly microRNAs, in epithelial-to-mesenchymal transition in both developmental and pathological EMT.
\end{abstract}

Keywords: epithelial-to-mesenchymal transition; microRNA; lncRNAs; transcriptional regulation; post-transcriptional regulation

\section{Introduction}

Epithelial-to-mesenchymal transition (EMT) is a key biological process involved in a multitude of developmental and pathological events. It is characterized by the progressive loss of cell-to-cell contacts, changes in cell polarity, and cleavage and invasion of the basal lamina produced by actin cytoskeletal rearrangements, leading to filopodia formation and finally to progressive up-regulation of mesenchymal gene expression. At the molecular level, epithelial cells are characterized by the expression of epithelial (E)-cadherin, ZO-1, occludin, cytokeratins, claudins, and type IV collagen, while mesenchymal cells are characterized by vimentin, $\alpha$-SMA, FSP-1, fibronectin, neural (N)-cadherin, and secretion of type I and III collagens. Transition from an epithelial to mesenchymal phenotype is produced by up-regulation of a subset of transcription factors, such as Snail/Slug, Twist and Zeb1/2. Regulatory mechanisms driving the expression of these transcription factors is modulated by several 
signaling pathways, including TGF- $\beta$ / BMP, Notch, Wnt/ $\beta$-catenin, receptor tyrosine kinase (Rtk) and Hedgehog [1,2]. Therefore, regulation of EMT is a complex process that is tightly regulated in different biological events. Epithelial-to-mesenchymal transition is a reversible process, and therefore in certain circumstances mesenchymal-to-epithelial transition (MET) can also take place, particularly during oncogenic processes [3-5]. Regulatory mechanisms driving MET fall beyond the scope of the present review (see for excellent reviews on MET [6-8]).

First EMT events during embryogenesis are observed at very early developmental stages, i.e., during gastrulation. Epiblast cell layer receives positional information to initiate an antero-posterior differentiation from epithelial cells to the underlying space leading to the formation of the third embryonic layer, the mesoderm. Epithelial-to-mesenchymal transition is a widely conserved developmental process during gastrulation across the animal kingdom, spanning from cnidarians [9,10], insects [11], fishes [12], and avians [13,14] to mammalians [15-17], using a wide variety of different signaling pathways [18-21]. Additional EMT events occur during embryonic development of several organs, such as gonadal development [22], the formation of the eye lens and retinal pigmented epithelium [23-31], the tubulogenesis and renal epithelial morphogenesis during kidney development [32-34], the formation of the stromal cells in the liver [35], the formation of $\beta$-pancreatic cells [36,37], and also during cardiovascular system development [38-40], involving signaling pathways such as TGF- $\beta$ /BMP [41-43] and Notch [44]. In fact, during cardiac development, two separate EMT events take place, one during the formation of the atrioventricular and semilunar valves [45-47], a process that is highly conserved in fishes [48,49] and avian and mammalian species [50-52]. In addition, a second EMT process occurs during cardiac development after the initial epicardial layer formation and subsequent invasion into the developing ventricular chambers, involving similar upstream signaling pathways, i.e., TGF- $\beta$ /BMP signaling [53-57], but curiously independently of Snail, at least in mice [58], and thus requiring additional regulatory player such as PDGF [59], Wt1 and Tbx18 [60,61].

In addition to those developmental events in which EMT plays a fundamental role, EMT is also determinant in several pathophysiological conditions, in particular in cancer. Multiple sets of evidence demonstrate that EMT is involved in oncogenic processes of different tissues such as in the gonads in the development of ovarian surface epithelial cancer [62-65], in the kidney in clear cell renal cell carcinoma [66-70], in the lungs leading to both adenocarcinoma and non-small cellular lung cancer (NSCLC) [71-75], in the liver in cholangiocarcinoma and hepatocellular carcinoma [76-79], and in the pancreas [80-83] as well as in other tissues [84-91].

Over the last decade our understanding of the molecular mechanisms driving EMT has greatly advanced. Multiple triggering signals, including TGF- $\beta / \mathrm{BMP}$, Notch, Wnt/ $\beta$-catenin, Rtk and Hedgehog signaling pathways converge into the activation of a core set of transcription factors [1,2] that initiate the conversion of epithelial to mesenchymal cells. In addition to the transcriptional modulation, a novel layer of gene regulatory mechanism is emerging, i.e., non-coding RNAs. Non-coding RNAs constitute a wide variety of RNA molecules with different functional and structural characteristics, including, among others, microRNAs (miRNAs) and long non-coding RNAs (lncRNAs) [92-94]. The implication of both types of non-coding RNAs in EMT has been revealed in embryonic development [95-98], cellular homeostasis [99-101], and physiopathological conditions [102-104], and more extensively in oncogenic diseases, such as for example those affecting the urogenital system [105-113]. Importantly, cross-talk between both types of non-coding RNAs (ncRNAs) is also emerging as demonstrated in multiple oncogenic settings, including renal cell carcinoma [114], ovarian cancer [115], squamous cell carcinoma [116], and hepatocellular carcinoma [117,118]. Importantly, ncRNAs are also equally implicated in the reverse mode of EMT, i.e., MET [119,120]. In the following subheadings the functional contribution of microRNAs in particular, and to a lesser extent long non-coding RNA, will be discussed and their interconnections on the regulation of core transcriptional regulatory mechanisms driving EMT in development and disease. The emerging role of lncRNAs in EMT have been recently revised in different pathological conditions $[118,121]$. Some evidence 
demonstrates that microRNAs can regulate EMT by modulating upstream signaling pathways such as TGF- $\beta$ [122-131], Wnt/ $\beta$-catenin [132-134], Notch [135], and Hedgehog [136] signaling, respectively, both in normal and pathological conditions. We have focused this review on dissecting the functional roles of microRNAs and lncRNAs within two levels of EMT processes. Firstly, the regulatory roles of these ncRNAs in the expression and function of those transcription factors involved in the initiation of the EMT process are elucidated, and secondly, a report on the regulation of those proteins that effectively confer migratory capacities to those mesenchymal cells is provided.

\section{Contribution of microRNAs to Epithelial-To-Mesenchymal Transition Regulation}

MicroRNAs are a subset of small non-coding RNAs of 22-24 nucleotides in length that can post-transcriptionally modulate gene expression by binding to the $3^{\prime}$ untranslated region of coding RNAs by base-pair complementarity and inducing protein translation blockage and/or messenger RNA (mRNA) degradation [92]. Such capabilities are provided by the seed sequence, i.e., six nucleotides stretch spanning from positions 2 to 8 in the mature microRNA molecule. MicroRNAs are encoded in the nucleus, transcribed by RNA polymerase II and polyadenylated in form of pre-miRNAs and/or pri-miRNA precursor molecules depending whether they are derived from monocystronic or polycistronic miRNAs molecules, respectively [92]. At present over 1500 microRNAs have been identified in humans (http:/ / www.mirbase.org). MicroRNAs that share the same functional seed sequence, such as for example miR-195a and miR-195b, even if they are located at different chromosomal positions, exert similar functional capabilities.

At present at least five different transcription factors have been implicated directing EMT in both normal and pathological conditions; i.e., Snail, Slug, Twist, Zeb1 and Zeb2. Our current understanding on the regulation of these transcription factors by microRNAs during embryonic development and/or during tissue homeostasis is scarce. Several sets of evidence demonstrate that a limited number of microRNAs can regulate Twist [137] and/or Zeb1/Zeb2 [138] during development and/or tissue homeostasis. In the cardiovascular system our understanding of the regulatory roles of microRNAs during EMT is also in its infancy. Three microRNAs have been involved in EMT during endocardial cushion formation [139-141], i.e., miR-23, miR-126 and miR-199, all of them inhibiting EMT progression. Their functional properties are conserved in mice, chicken and zebrafish, supporting a wide evolutionary conservation. During epicardial to mesenchymal transition, our understanding of the regulatory role of microRNAs is also rather scarce [96-98]. Deletion of the microRNA processing enzyme Dicer leads to impaired epicardial formation, yet EMT is not severely affected [98]. In this context, miR-21 manipulation leads to impaired EMT progression and fibrogenic cell differentiation of epicardial-derived cells. On the other hand, in pathological conditions, all these transcription factors are distinctly modulated by microRNAs.

\subsection{Regulation of Snail by microRNAs}

A bulk of microRNAs have been identified to down-regulate Snail expression, blocking therefore the EMT process (Figure 1). miR-30a directly targets Snail, and therefore blocks EMT progression in NSCLC and serves as a potential biomarker for this oncogenic entity [142]. miR-30d, miR-137 and miR-34a block EMT and cell invasion in ovarian cancer $[143,144]$ while miR-148a and miR-153a exert similar functions via Snail down-regulation in hepatocellular carcinoma [145,146]. miR-204 and miR-486 directly block Snail expression in gastric cancer [147] and prostate cancer [148], respectively, suppressing EMT, invasion, migration, and metastasis. Importantly, miR-148a indirectly regulate Met which in turn leads to Snail downregulation [145] in hepatocellular carcinoma, and similar indirect effects have also been reported for miR-374 targeting Foxc1 in cervical cancer [149] and miR-433 targeting Met/Creb1 in bladder cancer [150], leading to Snail inhibition. Overall, these observations demonstrate that multiple microRNAs can target Snail, directly or indirectly, having similar phenotypical consequences. 
Several microRNAs can modulate Snail up-regulation therefore promoting EMT and thus cell migration, metastasis, and invasion (Figure 1). In this context, miR-145 down-regulation leads to enhanced Snail expression and increased EMT in osteosarcoma [151] and miR-5003 in breast cancer [152].

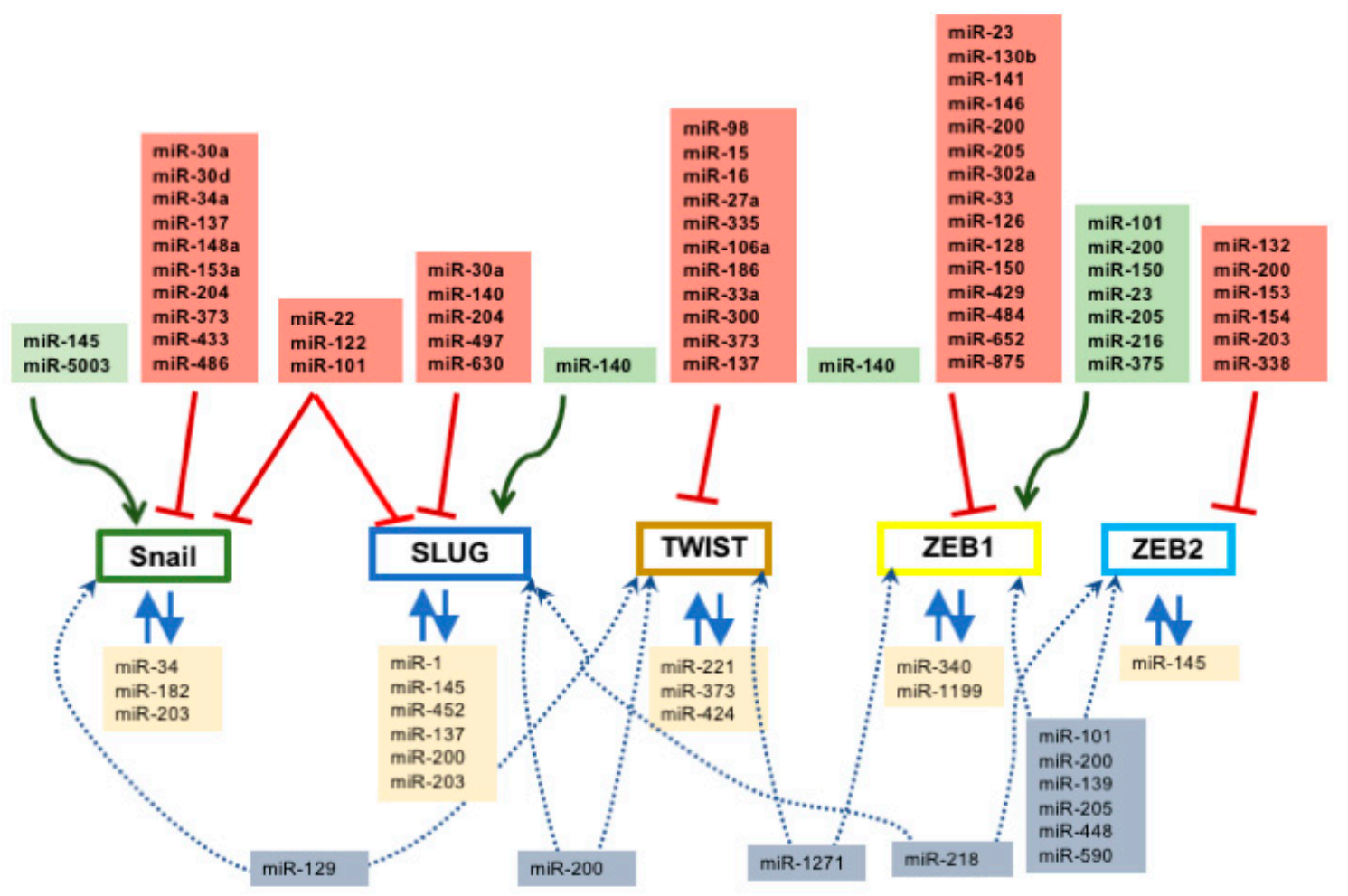

Figure 1. Schematic representation of the microRNAs regulating the epithelial-to-mesenchymal transition (EMT)-associated transcription factors Snail, Slug, Twist, Zeb1, and Seb2. Red lines demarcate inhibitory pathways, green lines demarcate activation pathways. Dotted lines delineate those microRNAs modulating the expression of different transcription factors, whereas blue arrows display regulatory loops.

\subsection{Regulation of Slug by microRNAs}

In addition to Snail, EMT is also controlled by Slug and therefore a subset of microRNAs has also been described to inhibit Slug expression and thus EMT progression (Figure 1). miR-30a and miR-497 inhibit EMT and metastasis in breast cancer $[153,154]$ while miR-204 and miR-630 inhibit EMT and tumor metastasis by targeting Slug in cholangiocarcinoma [155] and hepatocellular carcinoma [156], and miR-203 targets Slug in glioblastoma, promoting EMT [157]. On the other hand, downregulation of miR-140 leads to up-regulation of Slug and therefore to increased invasion in esophageal cancer [158].

\subsection{Co-Regulation of Snail and Slug by microRNAs}

Importantly, several microRNAs can directly influence expression of both Snail and Slug, promoting a more robust modulation of the EMT process. In the urogenital system, miR-22 plays a role controlling Snail/Slug expression in bladder cancer [159]. In the digestive tract, miR-122 is pivotal in hepatocellular carcinoma (HCC) [133] and miR-101 in oral tongue squamous cell carcinoma [160] (Figure 1).

Furthermore, auto-regulatory loops between different microRNAs and Snail and Slug have been described. In particular, Snail can regulate expression of miR-3 and this microRNA can also regulate Snail expression $[144,161,162]$, a regulatory mechanism that has indeed been described in both normal tissue homeostasis [161,162] and pathologic contexts such as ovarian cancer [162]. miR-34 directly 
targets Snail 3' untranslated region (UTR), leading to Snail down-regulation, while Snail, in conjunction with other EMT-related transcription factors such as Zeb1, binds the miR-34 promoter generating such a regulatory loop. In addition, Slug can mediate miR-452, miR-137, and miR-145 expression by directly binding to their promoters, leading in this way to tumor invasion and metastasis [163-165]. miR-203 can promote a feedback regulatory loop with Snail interacting at the same time with the miR-200-Zeb1 regulatory loop [166]. Similar regulatory loops are also reported for miR-182-Snail blocking metastasis in breast cancer [167], miR-1-Slug and miR-200-Slug inhibiting tumorigenesis in prostate cancer [168], and miR-203-Slug in breast cancer [169].

\subsection{Regulation of Twist by microRNAs}

The transcription factor Twist is also modulated by multiple microRNAs during EMT in several tissues (Figure 1). miR-98 regulates Twist expression in the respiratory system, in particular in NSCLC [170]. In the digestive tract, several microRNAs play a role in distinct oncogenic processes, miR-15, miR-16, miR-335 and miR-137 are involved in gastric cancer $[171,172]$ and colorectal cancer [173], while miR-27a is involved in hepatic cancer [174] and miR-106a in endometrial cancer [175] leading in both cases to direct downregulation of Twist by targeting its $3^{\prime}$ UTR. miR-186 also regulate Twist expression in the oncogenic processes of the urogenital tract, in particular in ovarian [176] and prostate cancer [177] while miR-300 can inhibit Twist expression leading to EMT blockage in melanoma [178]. Importantly, down-regulation of miR-106a, mediated by PDGF signaling, leads to Twist up-regulation and thus EMT progression in hepatoma cells [179] while the opposite phenotypical consequences are observed by the IL6-mediated regulation of miR-33a leading to Twist downregulation and thus suppression of tumor progression in gallbladder cancer [180]. Feed-forward mechanisms also provide regulatory loops for miR-373, miR-221, miR-424, and Twist [181,182] in different oncogenic processes, involving targeting of the Twist $3^{\prime} \mathrm{UTR}$ by the corresponding miRNAs and promoter regulation by Twist. In addition, miR-221 and miR-424, Twist-regulated microRNAs, are also involved in EMT regulation, leading to increased metastasis in cervical cancer [183] and breast cancer [184].

\subsection{Regulation of Zeb1 and Zeb2 by microRNAs}

The largest number of microRNAs are known to modulate Zeb1 and Zeb2 expression during EMT (Figure 1). In particular, several of these microRNA-Zeb1/Zeb2 interactions have been reported in normal and pathological adult tissues. miR-130b [185], miR-146 [186,187], miR-200 [188-192], and miR-205 [193] regulate Zeb1, modulating EMT under normal physiological conditions, while miR-302a regulates EMT in diabetic kidney disease [194]. Importantly, miR-200 family members [192,195] can also modulate both Zeb1 and Zeb2 simultaneously and evidence shows that Snail can be equally modulated [196]. In oncogenic conditions, a large array of microRNAs have also been reported to inhibit Zeb1 expression leading therefore to EMT blockage: miR-33 in adenocarcinoma [197], miR-126 in osteosarcoma [198], miR-128 in esophageal squamous cell cancer [199], miR-150 [200] and miR-200 in ovarian [201] and breast cancer [202], miR-205 [203] and miR-429 [204] and miR-484 [205] in cervical carcinoma, miR-652 in pancreatic cancer [206], miR-875 in prostate cancer [207], miR-23 in bladder cancer [208] and miR-205 in glioblastoma [209]. On the other hand, up-regulation of Zeb1 is also modulated by several microRNAs such as miR-101 [210], miR-200 and miR-150 in colon carcinoma [211,212] and indirectly by miR-200 downregulation in breast cancer [213]. Furthermore, Zeb1 can directly regulate miR-375 expression by directly binding to its promoter, leading to transcriptional repression and thus activation of EMT in prostate cancer [214].

Zeb2 is also regulated by a large number of microRNAs. Several of them inhibit Zeb2 expression leading to decreased EMT, such as miR-132 in colorectal cancer [215] and lung cancer [216], miR-153 in ovarian cancer [217], miR-154 in NLCLC [218], miR-203 in adenocarcinoma [219] and nasopharyngeal carcinoma [220], miR-338 in gastric cancer [221], and members of the miR-200 family in glioma 
cells [222], gastric carcinoma [223,224], and NSCLC [225], while no evidence has been reported to date on up-regulation of Zeb2 by microRNA deregulation.

Similar to Snail/Slug and Twist, feed-forward regulatory mechanisms are operative for Zeb1/Zeb2 and microRNAs. Reciprocal repression between the Zeb1 and miR-200 family promotes EMT and thus cancer migration and invasion [226,227], a regulatory mechanism that is also reported for miR-1199-Zeb1 interactions [228]. Likewise, miR-340 and Zeb1 display a feed-forward loop involved in breast cancer progression [229], and miR-145 and Zeb2 leading to prostate cancer [230].

Furthermore, a large set of microRNAs co-regulates expression of both Zeb1 and Zeb2, modulating therefore tumor progression, for example miR-101 in ovarian carcinoma [231], miR-200 [232-235] in gastric adenocarcinoma, miR-139 in HCC [236], miR-205 [237] and miR-448 in breast cancer [238], and miR-590 in glioblastoma [239].

\subsection{Co-Regulation of Epithelial-To-Mesenchymal Transition-Associated Transcription Factors by microRNAs}

Importantly, co-regulation between these transcription factors is also applicable. miR-129 can simultaneously regulate Twist and Snail expression [182], miR-200 co-regulates Slug and Zeb1, miR-1271 co-regulates Twist and Zeb1 [240], miR-218 regulates Slug and Zeb2 [241] and miR-200 co-regulates Zeb1 and Snail $[196,242]$. These data demonstrate a complex and diverse regulatory role of microRNAs in EMT progression.

\subsection{Regulation of Cell-Cell Contact and Cytoskeletal Proteins by microRNAs}

In addition to the regulatory mechanisms exerted by microRNAs at the level of EMT-associated signaling pathways and key orchestrating transcription factors, several studies also pointed out a role for microRNAs directly regulating cell-cell contact and cytoskeletal proteins (Figure 2). Three different microRNAs-miR-122, miR-24, and miR-1291—can directly target RhoA expression [124,243,244] while miR-22 can similarly influence vimentin expression [158] providing therefore signaling cues to modify the cytoskeletal organization during the transition from epithelium to mesenchyme. A number of microRNAs have been reported to regulate cadherin and claudin expression (Figure 2). In particular, miR-10b and miR-214 have been reported to directly regulate E-cadherin by targeting its $3^{\prime}$ UTR $[105,245]$, while indirect regulation of E-cadherin is mediated by multiple microRNAs such as e.g., members of the miR-200 family cadherin [188,232-234]. Furthermore, miR-27a directly regulates vascular endothelial (VE)-cadherin [173], while miR-199a modulates $\mathrm{N}$-cadherin expression [126]. Claudin 1 and Claudin 5 are also directly targeted by microRNAs, such as miR-155 and miR-30a, respectively $[246,247]$. Importantly, evidence on the cytoskeletal and cell-cell contact proteins has been only reported in oncogenic processes, while no reports are currently available for normal embryological and/or homeostatic processes.

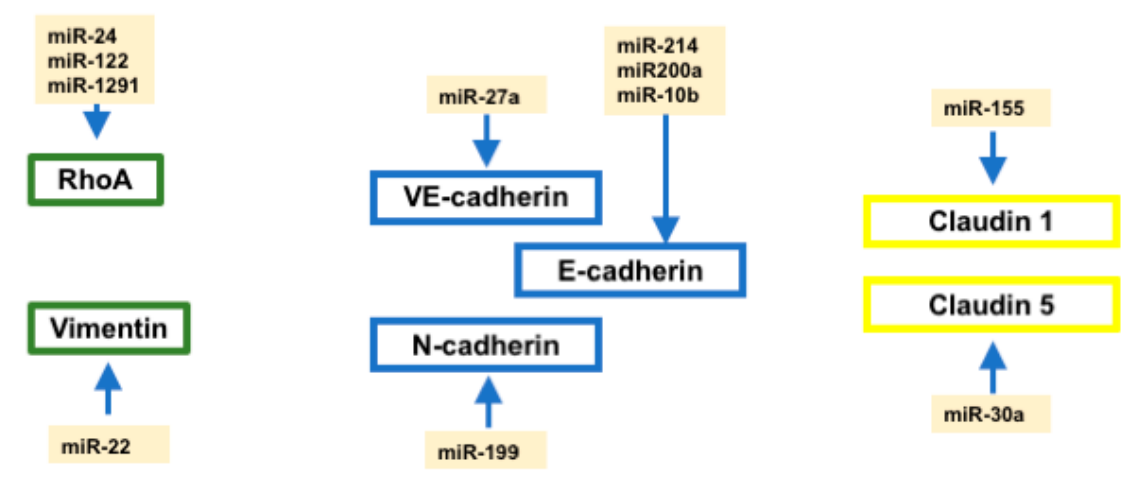

Figure 2. Schematic representation of the microRNAs regulating cytoskeletal and cell-cell contact proteins associated with EMT progression. Abbreviations: VE-cadherin, vascular-endothelial cadherin; E-cadherin, epithelial cadherin; N-cadherin, neural cadherin. 
In addition to those mechanisms driving microRNA-mediated regulation of EMT transcription factors, cell-cell contact, and cytoskeletal proteins, a large number of additional studies have reported the fundamental role of microRNAs regulating additional molecular targets involved in EMT, in particular during oncogenic processes [248-257]. Among these mechanisms it is important to highlight the emerging functional role of epigenetic regulation of microRNAs during EMT. Several studies reported that hypermethylation and/or demethylation of miRNA promoters can influence expression of EMT progression, such as for miR-211 [258,259] in melanoma cells, miR-129 [260] in HCC, miR-124 [261] in endometrial cancer, and miR-200 [262] and miR-203 [263] in distinct cell types. In some cases, epigenetic modulation of miRNA expression leads to up-regulation of TGF- $\beta$ signaling such as for miR-142 [264] in HCC or to epigenetic modulators such as HDAC5 [265] in NSCLC. Alternatively, miRNAs can directly target epigenetic modulators such as DNMT1 by miR-152 [266] or lysine K demethylase 6B by miR-941 [267] leading to impaired EMT development, respectively. Importantly, the epigenetic regulation of EMT involves multiple microRNAs within different tissues. For further reading, excellent reviews have been recently published on the topic [268-273]. There is also emerging evidence on the role of epigenetics in MET [274]. Additional studies will be therefore required to fully implement the cross roads between epigenetics microRNAs, EMT/MET and all these molecular partners.

\section{Contribution of Long Non-Coding RNAs to Epithelial-To-Mesenchymal Transition Regulation}

In contrast to microRNAs, our current understanding of long non-coding RNAs is limited. The development of new massive sequencing techniques has led to the discovery and annotation of a large number of long non-coding RNAs, i.e., 96,308 lncRNA genes [275]. These estimates indicate that the number of lncRNAs is twice that of coding genes, supporting an important role of these lncRNA transcripts in multiple biological contexts. Recently, lncRNAs have emerged as major players in regulating gene expression, both at transcriptional and post-transcriptional levels, and they have been implicated in development, stem cell differentiation, cellular homeostasis, and disease [276-278]. Long non-coding RNAs display essentially no potential to code for proteins, although structurally are similar to mRNAs. They are normally transcribed by RNA polymerase II, have typical histone modifications, have $5^{\prime}$ terminal cap and $3^{\prime}$ terminal poly(A) tails, are structured by exons and introns, and are often spliced. Although the vast majority of lncRNAs are located in the nuclear genome, lncRNAs are also reported within the mitochondrial DNA. Mitochondrial-encoded lncRNAs are transcribed and processed by mitochondrial transcriptional machinery but are regulated by nuclear encoded proteins [278,279]. Importantly, although lncRNAs are referred to as non-coding, some lncRNAs contain short open reading frames (ORFs) and can be engaged by ribosomes, and thus can generate oligopeptides, although this is mostly limited to sporadic cases.

Over the last years the relevance of long non-coding RNAs has emerged. Multiple studies demonstrate that differential expressions of IncRNAs can serve as biomarkers in different oncogenic conditions [280-283]. A large array of evidence demonstrates that distinct lncRNAs can influence EMT [284-292] by regulating upstream signaling pathways such as TGF- $\beta$ [293,294] or Wnt/ $\beta$-catenin [295] (Figure 3). In addition, IncRNAs such as UCA1 can regulate Slug expression [296], PVT1 and CHRF influence Twist function [297,298], and several other lncRNAs such as SNHG16, NEAT1 and HULC have been reported to modulate Zeb1 [299-302] and UICLM to Zeb2 [303] function, respectively (Figure 3 ). 


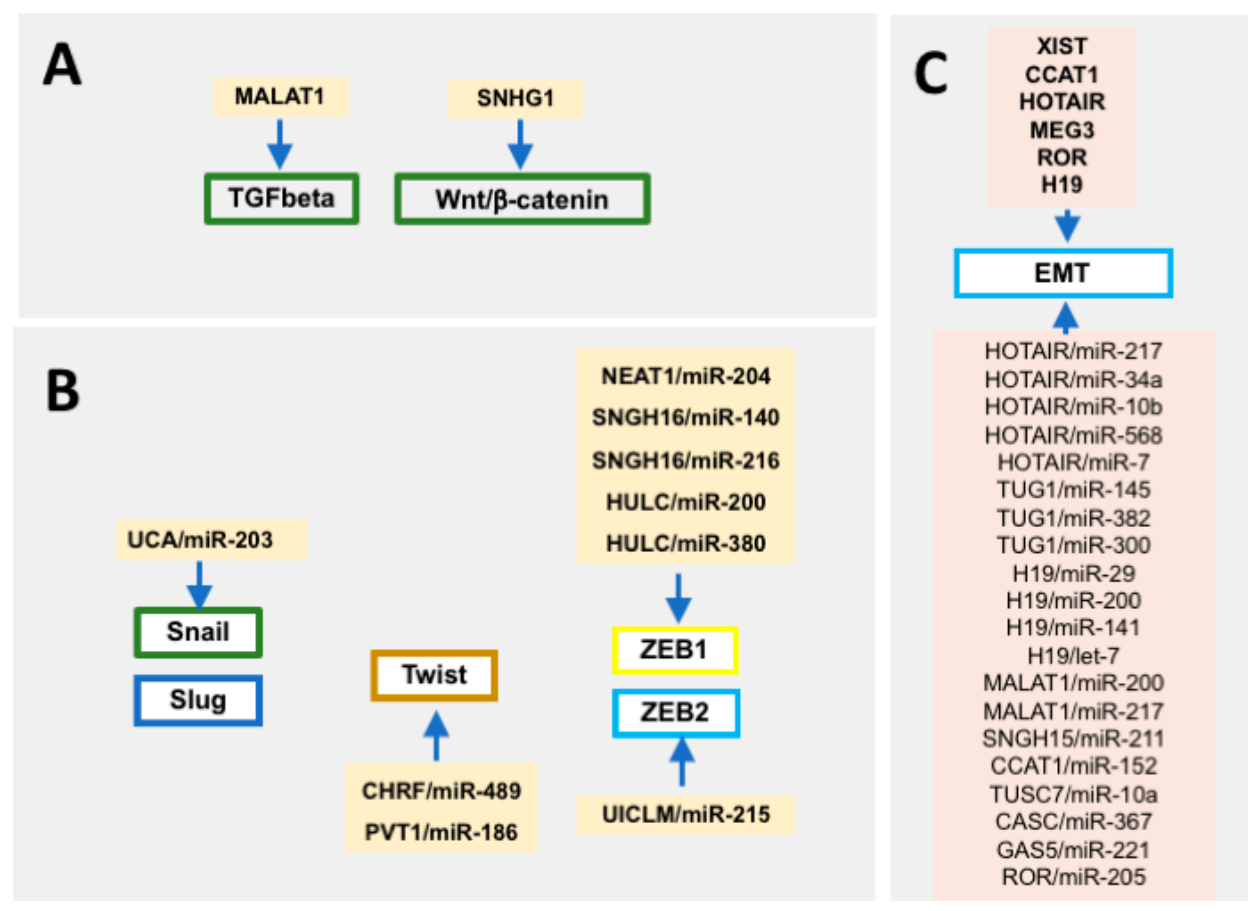

Figure 3. Schematic representation of the long non-coding RNA (lncRNAs) regulating the EMT-associated transcription factors Snail, Slug, Twist, Zeb1, and Zeb2.

\section{Cross-Talk between microRNAs and Long Non-Coding RNAs in Epithelial-To- Mesenchymal Transition}

Functional evidence has demonstrated that microRNAs can target lncRNAs, influencing therefore the functional role of these non-coding RNA molecules, and similarly, microRNA expression and function can be modulated by lncRNAs by acting as competing endogenous RNAs (ceRNAs) or as microRNA sponges. Evidence demonstrates that such microRNA-lncRNA cross-talks are operative in oncogenic processes (Figure 3). For example, TUG1 and miR-145 establish a double-negative feedback loop promoting EMT in human bladder cancer cells [304], while H19 and miR-141 regulate cell proliferation and migration in gastric cancer [305]. In fact, a large array of lncRNAs can act as ceRNAs or sponges of EMT-related microRNAs unraveling novel molecular pathways that promote and/or inhibit EMT [306-315]. For example, lncRNA SNHG15 sponges miR-211 in breast cancer [306] and CCAT1 sponges miR152 in cholangiocarcinoma [307]. Importantly, a single lncRNA can sponge several microRNAs in different cellular contexts-H19 for example can modulate miR-29 and miR-200 expression in bladder [309] and breast [120] cancer, respectively. On the other hand, a single microRNA can be sponged by several lncRNAs, for example miR-200 by H19 [120] and MALAT1 [310] in separate biological contexts, i.e., breast and endometrium cancer, respectively. Furthermore, within the same oncogenic process, distinct IncRNA-microRNA interactions have been described, as in hepatocellular carcinoma leading to Unigene56159-miR-140 [311], TUSC7-miR-109 [312], and CASC2-miR-367 [314] interactions, respectively. In other contexts, the regulatory roles of lncRNAs are manifested by modulation of microRNA expression, yet the precise molecular regulatory circuitries remain to be elucidated [315-325].

\section{Conclusions and Perspectives}

In this review we have highlighted the pivotal role of non-coding RNAs in several aspects of the epithelial-to-mesenchymal transition. Evidence demonstrates that EMT activators, i.e., upstream signaling pathways such as TGF- $\beta$ and Wnt signaling, can modulate the expression of a wide variety of microRNAs impacting on the functional properties of the EMT regulators (i.e., transcription factors) 
and thus on EMT progression. Similarly, transcription factor regulators of EMT can control the expression of a variety of microRNAs having an impact on individual EMT effectors, leading to cell-cell contact and cytoskeletal rearrangements. Thus, these data demonstrate a complex interplay between EMT activators, regulators, and effectors, and microRNAs. Furthermore, a novel layer of complexity is added as an additional subtype of non-coding RNAs, i.e., long non-coding RNAs can also interact with microRNAs, unraveling novel gene regulatory networks in the progression and development of EMT (Figure 4).

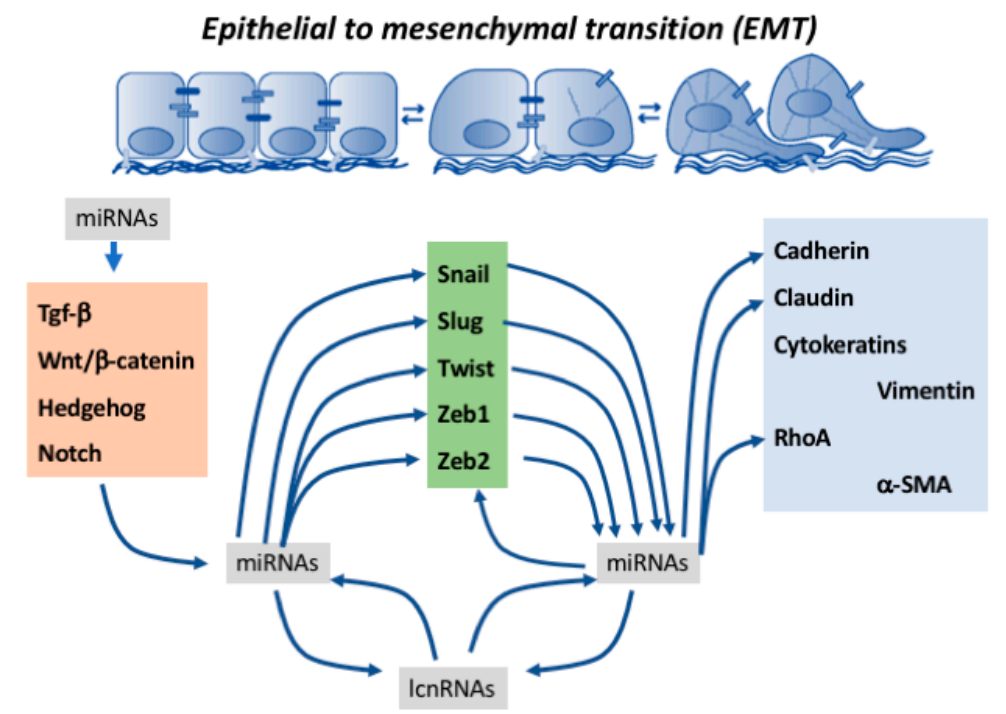

Figure 4. Schematic representation of the microRNA-lncRNA interactions regulating EMT progression.

Our understanding on the molecular mechanisms of EMT and the implication of the signaling pathways involved, as well as transcription factors driving EMT during embryonic development, has greatly advanced over the last decade. Surprisingly, our current understanding of the regulatory roles exerted by non-coding RNAs during embryonic development is scarce, as it is during adult tissue homeostasis. On the other hand, a large set of evidence has been reported in oncogenic processes, providing evidence that non-coding RNAs such as microRNAs and lncRNAs influence cell tissue homeostasis favoring in many cases pathological EMT. Additionally, they can also serve as potential biomarkers of ongoing oncogenic diseases and most importantly will potentially be used as therapeutic tools.

Mechanistically, multiple microRNAs have been described to target EMT-associated transcription factors such as Snail, Slug, Twist, Zeb1, and Zeb2, respectively, in different cellular substrates. It is well-known that a single mRNA transcript can be targeted by multiple microRNAs and similarly that a single microRNA can target multiple mRNA transcripts. Thus, it is not surprising that multiple microRNAs can target these EMT transcription factors. However, with the exception of the miR-200 family, current evidence mostly demonstrates a tissue-specific role for a single microRNA, highlighting the importance of the tissue-specific expression of these non-coding RNAs and their corresponding deregulation in a tissue-specific manner. To date, information on the cellular distribution of these regulatory molecules remains scarce.

In addition to microRNAs, a novel layer of complexity on the regulation of EMT progression is emerging as long non-coding RNAs have been widely demonstrated to play pivotal roles. Several sets of evidence demonstrate that lncRNAs can act as sponge of distinct microRNAs, therefore impacting on the progression of EMT. In other cases, IncRNAs can regulate microRNAs by, to date, unclear mechanisms. Given the wide variety of functional properties revealed for lncRNAs in other biological contexts, it is plausible that in the near future, additional roles for these non-coding RNAs will be 
identified in the context of EMT development. In this setting, lncRNAs can also be postulated as biomarkers of oncogenic diseases, and manipulation of these emerging regulatory molecules might also serve in the near future as a therapeutic tool to control EMT progression and the fatal consequences of pathological EMT, i.e., migration, invasion, and metastasis.

Author Contributions: A.E.V. performed the corresponding literature search and wrote a draft version of the manuscript. D.F. revised and edited the manuscript and provided the corresponding figures. A.E.A. revised the final version of the manuscript.

Acknowledgments: This work was partially supported by grants BFU2012-38111, BFU2015-67131 (Ministerio de Economía y Competitividad, Gobierno de España, Spain) and CTS-1614 (Junta de Andalucia, Spain).

Conflicts of Interest: The authors declare no conflict of interest.

\section{References}

1. Gonzalez, D.M.; Medici, D. Signaling mechanisms of the epithelial-mesenchymal transition. Sci. Signal. 2014, 7, re8. [CrossRef] [PubMed]

2. Lamouille, S.; Xu, J.; Derynck, R. Molecular mechanisms of epithelial-mesenchymal transition. Nat. Rev. Mol. Cell Biol. 2014, 15, 78-96. [CrossRef] [PubMed]

3. Patel, N.; Garikapati, K.R.; Makani, V.K.K.; Nair, A.D.; Vangara, N.; Bhadra, U.; Pal Bhadra, M. Regulating BMI1 expression via miRNAs promote Mesenchymal to Epithelial Transition (MET) and sensitizes breast cancer cell to chemotherapeutic drug. PLoS ONE 2018, 13, e0190245. [CrossRef] [PubMed]

4. Drago-García, D.; Espinal-Enríquez, J.; Hernández-Lemus, E. Network analysis of EMT and MET micro-RNA regulation in breast cancer. Sci. Rep. 2017, 7, 13534. [CrossRef] [PubMed]

5. Ware, K.E.; Gilja, S.; Xu, S.; Shetler, S.; Jolly, M.K.; Wang, X.; Bartholf Dewitt, S.; Hish, A.J.; Jordan, S.; Eward, W.; et al. Induction of Mesenchymal-Epithelial Transitions in Sarcoma Cells. J. Vis. Exp. $2017,122$. [CrossRef] [PubMed]

6. Forte, E.; Chimenti, I.; Rosa, P.; Angelini, F.; Pagano, F.; Calogero, A.; Giacomello, A.; Messina, E. EMT/MET at the Crossroad of Stemness, Regeneration and Oncogenesis: The Ying-Yang Equilibrium Recapitulated in Cell Spheroids. Cancers 2017, 9, 98. [CrossRef] [PubMed]

7. Hamilton, G.; Rath, B. Mesenchymal-Epithelial Transition and Circulating Tumor Cells in Small Cell Lung Cancer. Adv. Exp. Med. Biol. 2017, 994, 229-245. [PubMed]

8. Barui, A.; Chowdhury, F.; Pandit, A.; Datta, P. Rerouting mesenchymal stem cell trajectory towards epithelial lineage by engineering cellular niche. Biomaterials 2018, 156, 28-44. [CrossRef] [PubMed]

9. Fritzenwanker, J.H.; Saina, M.; Technau, U. Analysis of forkhead and snail expression reveals epithelial-mesenchymal transitions during embryonic and larval development of Nematostella vectensis. Dev. Biol. 2004, 275, 389-402. [CrossRef] [PubMed]

10. Kraus, Y.; Technau, U. Gastrulation in the sea anemone Nematostella vectensis occurs by invagination and immigration: An ultrastructural study. Dev. Genes Evol. 2006, 216, 119-132. [CrossRef] [PubMed]

11. Smallhorn, M.; Murray, M.J.; Saint, R. The epithelial-mesenchymal transition of the Drosophila mesoderm requires the Rho GTP exchange factor Pebble. Development 2004, 131, 2641-2651. [CrossRef] [PubMed]

12. Yamashita, S.; Miyagi, C.; Fukada, T.; Kagara, N.; Che, Y.S.; Hirano, T. Zinc transporter LIVI controls epithelial-mesenchymal transition in zebrafish gastrula organizer. Nature 2004, 429, 298-302. [CrossRef] [PubMed]

13. Chuai, M.; Weijer, C.J. Regulation of cell migration during chick gastrulation. Curr. Opin. Genet. Dev. 2009, 19, 343-349. [CrossRef] [PubMed]

14. Nakaya, Y.; Sukowati, E.W.; Alev, C.; Nakazawa, F.; Sheng, G. Involvement of dystroglycan in epithelial-mesenchymal transition during chick gastrulation. Cells Tissues Organs 2011, 193, 64-73. [CrossRef] [PubMed]

15. Xiao, Z.; Patrakka, J.; Nukui, M.; Chi, L.; Niu, D.; Betsholtz, C.; Pikkarainen, T.; Vainio, S.; Tryggvason, K. Deficiency in Crumbs homolog 2 ( $\mathrm{Cr} b 2)$ affects gastrulation and results in embryonic lethality in mice. Dev. Dyn. 2011, 240, 2646-2656. [CrossRef] [PubMed] 
16. Trask, M.C.; Tremblay, K.D.; Mager, J. Yin-Yang1 is required for epithelial-to-mesenchymal transition and regulation of Nodal signaling during mammalian gastrulation. Dev. Biol. 2012, 368, 273-282. [CrossRef] [PubMed]

17. Zohn, I.E.; Li, Y.; Skolnik, E.Y.; Anderson, K.V.; Han, J.; Niswander, L. p38 and a p38-interacting protein are critical for downregulation of E-cadherin during mouse gastrulation. Cell 2006, 125, 957-969. [CrossRef] [PubMed]

18. Ohta, S.; Suzuki, K.; Tachibana, K.; Tanaka, H.; Yamada, G. Cessation of gastrulation is mediated by suppression of epithelial-mesenchymal transition at the ventral ectodermal ridge. Development 2007, 134, 4315-4324. [CrossRef] [PubMed]

19. Nakaya, Y.; Sukowati, E.W.; Wu, Y.; Sheng, G. RhoA and microtubule dynamics control cell-basement membrane interaction in EMT during gastrulation. Nat. Cell Biol. 2008, 10, 765-775. [CrossRef] [PubMed]

20. Ohta, S.; Schoenwolf, G.C.; Yamada, G. The cessation of gastrulation: BMP signaling and EMT during and at the end of gastrulation. Cell Adhes. Migr. 2010, 4, 440-446. [CrossRef] [PubMed]

21. Howard, S.; Deroo, T.; Fujita, Y.; Itasaki, N. A positive role of cadherin in Wnt/ $\beta$-catenin signalling during epithelial-mesenchymal transition. PLoS ONE 2011, 6, e23899. [CrossRef] [PubMed]

22. Martinovic, V.; Vukusic Pusic, T.; Restovic, I.; Bocina, I.; Filipovic, N.; Saraga-Babic, M.; Vukojevic, K. Expression of Epithelial and Mesenchymal Differentiation Markers in the Early Human Gonadal Development. Anat. Rec. 2017, 300, 1315-1326. [CrossRef] [PubMed]

23. Matoba, R.; Morizane, Y.; Shiode, Y.; Hirano, M.; Doi, S.; Toshima, S.; Araki, R.; Hosogi, M.; Yonezawa, T.; Shiraga, F. Suppressive effect of AMP-activated protein kinase on the epithelial-mesenchymal transition in retinal pigment epithelial cells. PLoS ONE 2017, 12, e0181481. [CrossRef] [PubMed]

24. Liu, T.; Zhang, L.; Wang, Y.; Zhang, H.; Li, L.; Bao, X. Dickkopf-1 inhibits Wnt3a-induced migration and epithelial-mesenchymal transition of human lens epithelial cells. Exp. Eye Res. 2017, 161, 43-51. [CrossRef] [PubMed]

25. Tan, X.; Zhu, Y.; Chen, C.; Chen, X.; Qin, Y.; Qu, B.; Luo, L.; Lin, H.; Wu, M.; Chen, W.; et al. Sprouty2 Suppresses Epithelial-Mesenchymal Transition of Human Lens Epithelial Cells through Blockade of Smad2 and ERK1/2 Pathways. PLoS ONE 2016, 11, e0159275. [CrossRef] [PubMed]

26. Lai, K.; Luo, C.; Zhang, X.; Ye, P.; Zhang, Y.; He, J.; Yao, K. Regulation of angiogenin expression and epithelial-mesenchymal transition by HIF-1 $\alpha$ signaling in hypoxic retinal pigment epithelial cells. Biochim. Biophys. Acta 2016, 1862, 1594-1607. [CrossRef] [PubMed]

27. Zhang, G.; Kang, L.; Chen, J.; Xue, Y.; Yang, M.; Qin, B.; Yang, L.; Zhang, J.; Lu, H.; Guan, H. CtBP2 Regulates TGF $32-$ Induced Epithelial-Mesenchymal Transition Through Notch Signaling Pathway in Lens Epithelial Cells. Curr. Eye Res. 2016, 41, 1057-1063. [CrossRef] [PubMed]

28. Chang, K.C.; Petrash, J.M. Aldose Reductase Mediates Transforming Growth Factor $\beta 2$ (TGF- $\beta 2$ )-Induced Migration and Epithelial-To-Mesenchymal Transition of Lens-Derived Epithelial Cells. Investig. Ophthalmol. Vis. Sci. 2015, 56, 4198-4210. [CrossRef] [PubMed]

29. Chen, X.; Xiao, W.; Liu, X.; Zeng, M.; Luo, L.; Wu, M.; Ye, S.; Liu, Y. Blockade of Jagged/Notch pathway abrogates transforming growth factor $\beta 2$-induced epithelial-mesenchymal transition in human retinal pigment epithelium cells. Curr. Mol. Med. 2014, 14, 523-534. [CrossRef] [PubMed]

30. Li, H.; Li, M.; Xu, D.; Zhao, C.; Liu, G.; Wang, F. Overexpression of Snail in retinal pigment epithelial triggered epithelial-mesenchymal transition. Biochem. Biophys. Res. Commun. 2014, 446, 347-351. [CrossRef] [PubMed]

31. Bastiaans, J.; van Meurs, J.C.; van Holten-Neelen, C.; Nagtzaam, N.M.; van Hagen, P.M.; Chambers, R.C.; Hooijkaas, H.; Dik, W.A. Thrombin induces epithelial-mesenchymal transition and collagen production by retinal pigment epithelial cells via autocrine PDGF-receptor signaling. Investig. Ophthalmol. Vis. Sci. 2013, 54, 8306-8314. [CrossRef] [PubMed]

32. Pifer, P.M.; Farris, J.C.; Thomas, A.L.; Stoilov, P.; Denvir, J.; Smith, D.M.; Frisch, S.M. Grainyhead-like 2 inhibits the coactivator p300, suppressing tubulogenesis and the epithelial-mesenchymal transition. Mol. Biol. Cell 2016, 27, 2479-2492. [CrossRef] [PubMed]

33. Campanaro, S.; Picelli, S.; Torregrossa, R.; Colluto, L.; Ceol, M.; Del Prete, D.; D’Angelo, A.; Valle, G.; Anglani, F. Genes involved in TGF $\beta 1$-driven epithelial-mesenchymal transition of renal epithelial cells are topologically related in the human interactome map. BMC Genom. 2007, 8, 383. [CrossRef] [PubMed] 
34. Forino, M.; Torregrossa, R.; Ceol, M.; Murer, L.; Della Vella, M.; Del Prete, D.; D'Angelo, A.; Anglani, F. TGF $\beta 1$ induces epithelial-mesenchymal transition, but not myofibroblast transdifferentiation of human kidney tubular epithelial cells in primary culture. Int. J. Exp. Pathol. 2006, 87, 197-208. [CrossRef] [PubMed]

35. Chagraoui, J.; Lepage-Noll, A.; Anjo, A.; Uzan, G.; Charbord, P. Fetal liver stroma consists of cells in epithelial-to-mesenchymal transition. Blood 2003, 101, 2973-2982. [CrossRef] [PubMed]

36. Rukstalis, J.M.; Habener, J.F. Snail2, a mediator of epithelial-mesenchymal transitions, expressed in progenitor cells of the developing endocrine pancreas. Gene Exp. Patterns 2007, 7, 471-479. [CrossRef] [PubMed]

37. Cole, L.; Anderson, M.; Antin, P.B.; Limesand, S.W. One process for pancreatic $\beta$-cell coalescence into islets involves an epithelial-mesenchymal transition. J. Endocrinol. 2009, 203, 19-31. [CrossRef] [PubMed]

38. Lin, F.J.; You, L.R.; Yu, C.T.; Hsu, W.H.; Tsai, M.J.; Tsai, S.Y. Endocardial cushion morphogenesis and coronary vessel development require chicken ovalbumin upstream promoter-transcription factor II. Arterioscler. Thromb. Vasc. Biol. 2012, 32, e135-e146. [CrossRef] [PubMed]

39. Sakabe, M.; Ikeda, K.; Nakatani, K.; Kawada, N.; Imanaka-Yoshida, K.; Yoshida, T.; Yamagishi, T.; Nakajima, Y. Rho kinases regulate endothelial invasion and migration during valvuloseptal endocardial cushion tissue formation. Dev. Dyn. 2006, 235, 94-104. [CrossRef] [PubMed]

40. Morabito, C.J.; Dettman, R.W.; Kattan, J.; Collier, J.M.; Bristow, J. Positive and negative regulation of epicardial-mesenchymal transformation during avian heart development. Dev. Biol. 2001, 234, $204-215$. [CrossRef] [PubMed]

41. Yamagishi, T.; Ando, K.; Nakamura, H. Roles of TGF $\beta$ and BMP during valvulo-septal endocardial cushion formation. Anat. Sci. Int. 2009, 84, 77-87. [CrossRef] [PubMed]

42. Clark, C.R.; Robinson, J.Y.; Sanchez, N.S.; Townsend, T.A.; Arrieta, J.A.; Merryman, W.D.; Trykall, D.Z.; Olivey, H.E.; Hong, C.C.; Barnett, J.V. Common pathways regulate Type III TGF $\beta$ receptor-dependent cell invasion in epicardial and endocardial cells. Cell. Signal. 2016, 28, 688-698. [CrossRef] [PubMed]

43. Sridurongrit, S.; Larsson, J.; Schwartz, R.; Ruiz-Lozano, P.; Kaartinen, V. Signaling via the TGF- $\beta$ type I receptor Alk5 in heart development. Dev. Biol. 2008, 322, 208-218. [CrossRef] [PubMed]

44. Niessen, K.; Fu, Y.; Chang, L.; Hoodless, P.A.; McFadden, D.; Karsan, A. Slug is a direct Notch target required for initiation of cardiac cushion cellularization. J. Cell Biol. 2008, 182, 315-325. [CrossRef] [PubMed]

45. Dyer, L.; Lockyer, P.; Wu, Y.; Saha, A.; Cyr, C.; Moser, M.; Pi, X.; Patterson, C. BMPER Promotes Epithelial-Mesenchymal Transition in the Developing Cardiac Cushions. PLoS ONE 2015, 10, e0139209. [CrossRef] [PubMed]

46. Harikrishnan, K.; Cooley, M.A.; Sugi, Y.; Barth, J.L.; Rasmussen, L.M.; Kern, C.B.; Argraves, K.M.; Argraves, W.S. Fibulin-1 suppresses endothelial to mesenchymal transition in the proximal outflow tract. Mech. Dev. 2015, 136, 123-132. [CrossRef] [PubMed]

47. Chang, A.C.; Garside, V.C.; Fournier, M.; Smrz, J.; Vrljicak, P.; Umlandt, P.; Fuller, M.; Robertson, G.; Zhao, Y.; Tam, A.; et al. A Notch-dependent transcriptional hierarchy promotes mesenchymal transdifferentiation in the cardiac cushion. Dev. Dyn. 2014, 243, 894-905. [CrossRef] [PubMed]

48. Shin, S.H.; Lee, S.; Bae, J.S.; Jee, J.G.; Cha, H.J.; Lee, Y.M. Thymosin $\beta 4$ regulates cardiac valve formation via endothelial-mesenchymal transformation in zebrafish embryos. Mol. Cells 2014, 37, 330-336. [CrossRef] [PubMed]

49. Wyatt, L.; Wadham, C.; Crocker, L.A.; Lardelli, M.; Khew-Goodall, Y. The protein tyrosine phosphatase Pez regulates TGF $\beta$, epithelial-mesenchymal transition, and organ development. J. Cell Biol. 2007, 178, 1223-1235. [CrossRef] [PubMed]

50. Okagawa, H.; Markwald, R.R.; Sugi, Y. Functional BMP receptor in endocardial cells is required in atrioventricular cushion mesenchymal cell formation in chick. Dev. Biol. 2007, 306, 179-192. [CrossRef] [PubMed]

51. Song, L.; Fässler, R.; Mishina, Y.; Jiao, K.; Baldwin, H.S. Essential functions of Alk3 during AV cushion morphogenesis in mouse embryonic hearts. Dev. Biol. 2007, 301, 276-286. [CrossRef] [PubMed]

52. Liebner, S.; Cattelino, A.; Gallini, R.; Rudini, N.; Iurlaro, M.; Piccolo, S.; Dejana, E. $\beta$-catenin is required for endothelial-mesenchymal transformation during heart cushion development in the mouse. J. Cell Biol. 2004, 166, 359-367. [CrossRef] [PubMed]

53. Olivey, H.E.; Mundell, N.A.; Austin, A.F.; Barnett, J.V. Transforming growth factor- $\beta$ stimulates epithelial-mesenchymal transformation in the proepicardium. Dev. Dyn. 2006, 235, 50-59. [CrossRef] [PubMed] 
54. Compton, L.A.; Potash, D.A.; Mundell, N.A.; Barnett, J.V. Transforming growth factor- $\beta$ induces loss of epithelial character and smooth muscle cell differentiation in epicardial cells. Dev. Dyn. 2006, 235, 82-93. [CrossRef] [PubMed]

55. Hill, C.R.; Sanchez, N.S.; Love, J.D.; Arrieta, J.A.; Hong, C.C.; Brown, C.B.; Austin, A.F.; Barnett, J.V. BMP2 signals loss of epithelial character in epicardial cells but requires the Type III TGF $\beta$ receptor to promote invasion. Cell. Signal. 2012, 24, 1012-1022. [CrossRef] [PubMed]

56. Bax, N.A.; van Oorschot, A.A.; Maas, S.; Braun, J.; van Tuyn, J.; de Vries, A.A.; Groot, A.C.; Goumans, M.J. In vitro epithelial-to-mesenchymal transformation in human adult epicardial cells is regulated by TGF $\beta$-signaling and WT1. Basic Res. Cardiol. 2011, 106, 829-847. [CrossRef] [PubMed]

57. Dokic, D.; Dettman, R.W. VCAM-1 inhibits TGF $\beta$ stimulated epithelial-mesenchymal transformation by modulating Rho activity and stabilizing intercellular adhesion in epicardial mesothelial cells. Dev. Biol. 2006, 299, 489-504. [CrossRef] [PubMed]

58. Casanova, J.C.; Travisano, S.; de la Pompa, J.L. Epithelial-to-mesenchymal transition in epicardium is independent of snail1. Genesis 2013, 51, 32-40. [CrossRef] [PubMed]

59. Smith, C.L.; Baek, S.T.; Sung, C.Y.; Tallquist, M.D. Epicardial-derived cell epithelial-to-mesenchymal transition and fate specification require PDGF receptor signaling. Circ. Res. 2011, 108, e15-e26. [CrossRef] [PubMed]

60. Takeichi, M.; Nimura, K.; Mori, M.; Nakagami, H.; Kaneda, Y. The transcription factors Tbx18 and Wt1 control the epicardial epithelial-mesenchymal transition through bi-directional regulation of Slug in murine primary epicardial cells. PLoS ONE 2013, 8, e57829. [CrossRef] [PubMed]

61. Von Gise, A.; Zhou, B.; Honor, L.B.; Ma, Q.; Petryk, A.; Pu, W.T. WT1 regulates epicardial epithelial to mesenchymal transition through $\beta$-catenin and retinoic acid signaling pathways. Dev. Biol. 2011, 356, 421-431. [CrossRef] [PubMed]

62. Martínez-Ramírez, A.S.; Garay, E.; García-Carrancá, A.; Vázquez-Cuevas, F.G. The P2RY2 Receptor Induces Carcinoma Cell Migration and EMT Through Cross-Talk with Epidermal Growth Factor Receptor. J. Cell. Biochem. 2016, 117, 1016-1026. [CrossRef] [PubMed]

63. Yi, B.R.; Kim, T.H.; Kim, Y.S.; Choi, K.C. Alteration of epithelial-mesenchymal transition markers in human normal ovaries and neoplastic ovarian cancers. Int. J. Oncol. 2015, 46, 272-280. [CrossRef] [PubMed]

64. Adham, S.A.; Al Harrasi, I.; Al Haddabi, I.; Al Rashdi, A.; Al Sinawi, S.; Al Maniri, A.; Ba-Omar, T.; Coomber, B.L. Immunohistological insight into the correlation between neuropilin-1 and epithelial-mesenchymal transition markers in epithelial ovarian cancer. J. Histochem. Cytochem. 2014, 62, 619-631. [CrossRef] [PubMed]

65. Ahmed, N.; Thompson, E.W.; Quinn, M.A. Epithelial-mesenchymal interconversions in normal ovarian surface epithelium and ovarian carcinomas: An exception to the norm. J. Cell. Physiol. 2007, 213, 581-588. [CrossRef] [PubMed]

66. Rasti, A.; Madjd, Z.; Abolhasani, M.; Mehrazma, M.; Janani, L.; Saeednejad Zanjani, L.; Asgari, M. Cytoplasmic expression of Twist1, an EMT-related transcription factor, is associated with higher grades renal cell carcinomas and worse progression-free survival in clear cell renal cell carcinoma. Clin. Exp. Med. 2017, 18, 177-190. [CrossRef] [PubMed]

67. Landolt, L.; Eikrem, Ø.; Strauss, P.; Scherer, A.; Lovett, D.H.; Beisland, C.; Finne, K.; Osman, T.; Ibrahim, M.M.; Gausdal, G.; et al. Clear Cell Renal Cell Carcinoma is linked to Epithelial-to-Mesenchymal Transition and to Fibrosis. Physiol. Rep. 2017, 5, e13305. [CrossRef] [PubMed]

68. Zhang, S.; Hong, Z.; Chai, Y.; Liu, Z.; Du, Y.; Li, Q.; Liu, Q. CSN5 promotes renal cell carcinoma metastasis and EMT by inhibiting ZEB1 degradation. Biochem. Biophys. Res. Commun. 2017, 488, 101-108. [CrossRef] [PubMed]

69. Feldkoren, B.; Hutchinson, R.; Rapoport, Y.; Mahajan, A.; Margulis, V. Integrin signaling potentiates transforming growth factor- $\beta 1$ (TGF- $\beta 1$ ) dependent down-regulation of E-Cadherin expression-Important implications for epithelial to mesenchymal transition (EMT) in renal cell carcinoma. Exp. Cell Res. 2017, 355, 57-66. [CrossRef] [PubMed]

70. Zhao, Q.; Liu, T.; Hong, B.; Wang, F.; Zhou, C.; Du, X.; Chen, S.; Deng, X.; Duoerkun, S.; Li, Q.; et al. Vascular Endothelial Growth Inhibitor, a Cytokine of the Tumor Necrosis Factor Family, is Associated with Epithelial-Mesenchymal Transition in Renal Cell Carcinoma. Appl. Immunohistochem. Mol. Morphol. 2017. [CrossRef] [PubMed] 
71. Giacomelli, C.; Daniele, S.; Romei, C.; Tavanti, L.; Neri, T.; Piano, I.; Celi, A.; Martini, C.; Trincavelli, M.L. The A(2B) Adenosine Receptor Modulates the Epithelial-Mesenchymal Transition through the Balance of cAMP/PKA and MAPK/ERK Pathway Activation in Human Epithelial Lung Cells. Front. Pharmacol. 2018, 9, 54. [CrossRef] [PubMed]

72. Chae, Y.K.; Chang, S.; Ko, T.; Anker, J.; Agte, S.; Iams, W.; Choi, W.M.; Lee, K.; Cruz, M. Epithelial-mesenchymal transition (EMT) signature is inversely associated with T-cell infiltration in non-small cell lung cancer (NSCLC). Sci. Rep. 2018, 8, 2918. [CrossRef] [PubMed]

73. Wang, S.; Cheng, Y.; Gao, Y.; He, Z.; Zhou, W.; Chang, R.; Peng, Z.; Zheng, Y.; Duan, C.; Zhang, C. SH2B1 promotes epithelial-mesenchymal transition through the IRS1/ $\beta$-catenin signaling axis in lung adenocarcinoma. Mol. Carcinog. 2018, 57, 640-652. [CrossRef] [PubMed]

74. Luo, D.; Hu, S.; Tang, C.; Liu, G. Mesenchymal stem cells promote cell invasion and migration and autophagy-induced epithelial-mesenchymal transition in A549 lung adenocarcinoma cells. Cell Biochem. Funct. 2018, 36, 88-94. [CrossRef] [PubMed]

75. Zhang, Y.; Zhang, X.; Ye, M.; Jing, P.; Xiong, J.; Han, Z.; Kong, J.; Li, M.; Lai, X.; Chang, N.; et al. FBW7 loss promotes epithelial-to-mesenchymal transition in non-small cell lung cancer through the stabilization of Snail protein. Cancer Lett. 2018, 419, 75-83. [CrossRef] [PubMed]

76. Yamanaka, C.; Wada, H.; Eguchi, H.; Hatano, H.; Gotoh, K.; Noda, T.; Yamada, D.; Asaoka, T.; Kawamoto, K.; Nagano, H.; et al. Clinical significance of CD13 and epithelial mesenchymal transition (EMT) markers in hepatocellular carcinoma. Jpn. J. Clin. Oncol. 2018, 48, 52-60. [CrossRef] [PubMed]

77. He, Z.; Dong, W.; Hu, J.; Ren, X. AQP5 promotes hepatocellular carcinoma metastasis via NF-kB-regulated epithelial-mesenchymal transition. Biochem. Biophys. Res. Commun. 2017, 490, 343-348. [CrossRef] [PubMed]

78. Peng, R.; Zhang, P.F.; Zhang, C.; Huang, X.Y.; Ding, Y.B.; Deng, B.; Bai, D.S.; Xu, Y.P. Elevated TRIM44 promotes intrahepatic cholangiocarcinoma progression by inducing cell EMT via MAPK signaling. Cancer Med. 2018, 7, 796-808. [CrossRef] [PubMed]

79. Nishiyama, M.; Tsunedomi, R.; Yoshimura, K.; Hashimoto, N.; Matsukuma, S.; Ogihara, H.; Kanekiyo, S.; Iida, M.; Sakamoto, K.; Suzuki, N.; et al. Metastatic ability and the epithelial-mesenchyma transition in induced cancer stem-like hepatoma cells. Cancer Sci. 2018, 109, 1101-1109. [CrossRef] [PubMed]

80. He, Y.M.; Xiao, Y.S.; Wei, L.; Zhang, J.Q.; Peng, C.H. CUL4B Promotes Metastasis and Proliferation in Pancreatic Cancer Cells by Inducing Epithelial-Mesenchymal Transition via the Wnt/ $\beta$-catenin Signaling Pathway. J. Cell. Biochem. 2017. [CrossRef] [PubMed]

81. Puls, T.J.; Tan, X.; Whittington, C.F.; Voytik-Harbin, S.L. 3D collagen fibrillar microstructure guides pancreatic cancer cell phenotype and serves as a critical design parameter for phenotypic models of EMT. PLoS ONE 2017, 12, e0188870. [CrossRef] [PubMed]

82. Nishino, H.; Takano, S.; Yoshitomi, H.; Suzuki, K.; Kagawa, S.; Shimazaki, R.; Shimizu, H.; Furukawa, K.; Miyazaki, M.; Ohtsuka, M. Grainyhead-like 2 (GRHL2) regulates epithelial plasticity in pancreatic cancer progression. Cancer Med. 2017, 6, 2686-2696. [CrossRef] [PubMed]

83. Krebs, A.M.; Mitschke, J.; Lasierra Losada, M.; Schmalhofer, O.; Boerries, M.; Busch, H.; Boettcher, M.; Mougiakakos, D.; Reichardt, W.; Bronsert, P.; et al. The EMT-activator Zeb1 is a key factor for cell plasticity and promotes metastasis in pancreatic cancer. Nat. Cell Biol. 2017, 19, 518-529. [CrossRef] [PubMed]

84. Natsuizaka, M.; Whelan, K.A.; Kagawa, S.; Tanaka, K.; Giroux, V.; Chandramouleeswaran, P.M.; Long, A.; Sahu, V.; Darling, D.S.; Que, J.; et al. Interplay between Notch1 and Notch3 promotes EMT and tumor initiation in squamous cell carcinoma. Nat. Commun. 2017, 8, 1758. [CrossRef] [PubMed]

85. Shi, C.; Yang, X.; Bu, X.; Hou, N.; Chen, P. Alpha B-crystallin promotes the invasion and metastasis of colorectal cancer via epithelial-mesenchymal transition. Biochem. Biophys. Res. Commun. 2017, 489, 369-374. [CrossRef] [PubMed]

86. Liu, Y.; Lang, T.; Jin, B.; Chen, F.; Zhang, Y.; Beuerman, R.W.; Zhou, L.; Zhang, Z. Luteolin inhibits colorectal cancer cell epithelial-to-mesenchymal transition by suppressing CREB1 expression revealed by comparative proteomics study. J. Proteom. 2017, 161, 1-10. [CrossRef] [PubMed]

87. Dong, B.B.; Yan, J.S.; Yan, Y.Y.; Xie, T.C.; Xu, L.; Hu, G.H.; Xu, Y.F.; Liu, M. Downregulation of pigment epithelium-derived factor is associated with increased epithelial-mesenchymal transition in bladder cancer. Panminerva Med. 2017, 59, 9-14. [PubMed] 
88. Asnaghi, L.; Gezgin, G.; Tripathy, A.; Handa, J.T.; Merbs, S.L.; van der Velden, P.A.; Jager, M.J.; Harbour, J.W.; Eberhart, C.G. EMT-associated factors promote invasive properties of uveal melanoma cells. Mol. Vis. 2015, 21, 919-929. [PubMed]

89. Lv, N.; Shan, Z.; Gao, Y.; Guan, H.; Fan, C.; Wang, H.; Teng, W. Twist1 regulates the epithelial-mesenchymal transition via the NF-kB pathway in papillary thyroid carcinoma. Endocrine 2016, 51, 469-477. [CrossRef] [PubMed]

90. Wang, P. Suppression of DACH1 promotes migration and invasion of colorectal cancer via activating TGF- $\beta$-mediated epithelial-mesenchymal transition. Biochem. Biophys. Res. Commun. 2015, 460, 314-319. [CrossRef] [PubMed]

91. Keinan, O.; Kedan, A.; Gavert, N.; Selitrennik, M.; Kim, S.; Karn, T.; Becker, S.; Lev, S. The lipid-transfer protein Nir2 enhances epithelial-mesenchymal transition and facilitates breast cancer metastasis. J. Cell Sci. 2014, 127, 4740-4749. [CrossRef] [PubMed]

92. Bartel, D.P. MicroRNAs: Genomics, biogenesis, mechanism, and function. Cell 2004, 116, 281-297. [CrossRef]

93. Bär, C.; Chatterjee, S.; Thum, T. Long Noncoding RNAs in Cardiovascular Pathology, Diagnosis, and Therapy. Circulation 2016, 134, 1484-1499. [CrossRef] [PubMed]

94. Chen, L.L. Linking Long Noncoding RNA Localization and Function. Trends Biochem. Sci. 2016, 41, 761-772. [CrossRef] [PubMed]

95. Klattenhoff, C.A.; Scheuermann, J.C.; Surface, L.E.; Bradley, R.K.; Fields, P.A.; Steinhauser, M.L.; Ding, H.; Butty, V.L.; Torrey, L.; Haas, S.; et al. Braveheart, a long noncoding RNA required for cardiovascular lineage commitment. Cell 2013, 152, 570-583. [CrossRef] [PubMed]

96. Brønnum, H.; Andersen, D.C.; Schneider, M.; Sandberg, M.B.; Eskildsen, T.; Nielsen, S.B.; Kalluri, R.; Sheikh, S.P. miR-21 promotes fibrogenic epithelial-to-mesenchymal transition of epicardial mesothelial cells involving Programmed Cell Death 4 and Sprouty-1. PLoS ONE 2013, 8, e56280. [CrossRef] [PubMed]

97. Brønnum, H.; Andersen, D.C.; Schneider, M.; Nossent, A.Y.; Nielsen, S.B.; Sheikh, S.P. Islet-1 is a dual regulator of fibrogenic epithelial-to-mesenchymal transition in epicardial mesothelial cells. Exp. Cell Res. 2013, 319, 424-435. [CrossRef] [PubMed]

98. Singh, M.K.; Lu, M.M.; Massera, D.; Epstein, J.A. MicroRNA-processing enzyme Dicer is required in epicardium for coronary vasculature development. J. Biol. Chem. 2011, 286, 41036-41045. [CrossRef] [PubMed]

99. Antonello, Z.A.; Reiff, T.; Ballesta-Illan, E.; Dominguez, M. Robust intestinal homeostasis relies on cellular plasticity in enteroblasts mediated by miR-8-Escargot switch. EMBO J. 2015, 34, 2025-2041. [CrossRef] [PubMed]

100. Ke, J.; Zhao, Z.; Hong, S.H.; Bai, S.; He, Z.; Malik, F.; Xu, J.; Zhou, L.; Chen, W.; Martin-Trevino, R.; et al. Role of microRNA221 in regulating normal mammary epithelial hierarchy and breast cancer stem-like cells. Oncotarget 2015, 6, 3709-37021. [CrossRef] [PubMed]

101. Salviano-Silva, A.; Lobo-Alves, S.C.; Almeida, R.C.; Malheiros, D.; Petzl-Erler, M.L. Besides Pathology: Long Non-Coding RNA in Cell and Tissue Homeostasis. Noncoding RNA 2018, 4, 3. [CrossRef] [PubMed]

102. Deng, X.G.; Qiu, R.L.; Wu, Y.H.; Li, Z.X.; Xie, P.; Zhang, J.; Zhou, J.J.; Zeng, L.X.; Tang, J.; Maharjan, A.; et al. Overexpression of miR-122 promotes the hepatic differentiation and maturation of mouse ESCs through a miR-122/FoxA1/HNF4a-positive feedback loop. Liver Int. 2014, 34, 281-295. [CrossRef] [PubMed]

103. Kolesnikoff, N.; Attema, J.L.; Roslan, S.; Bert, A.G.; Schwarz, Q.P.; Gregory, P.A.; Goodall, G.J. Specificity protein 1 (Sp1) maintains basal epithelial expression of the miR-200 family: Implications for epithelial-mesenchymal transition. J. Biol. Chem. 2014, 289, 11194-11205. [CrossRef] [PubMed]

104. Liu, C.Y.; Zhang, Y.H.; Li, R.B.; Zhou, L.Y.; An, T.; Zhang, R.C.; Zhai, M.; Huang, Y.; Yan, K.W.; Dong, Y.H.; et al. LncRNA CAIF inhibits autophagy and attenuates myocardial infarction by blocking p53-mediated myocardin transcription. Nat. Commun. 2018, 9, 29. [CrossRef] [PubMed]

105. Liu, M.; Liu, L.; Bai, M.; Zhang, L.; Ma, F.; Yang, X.; Sun, S. Hypoxia-induced activation of Twist/miR-214/E-cadherin axis promotes renal tubular epithelial cell mesenchymal transition and renal fibrosis. Biochem. Biophys. Res. Commun. 2018, 495, 2324-2330. [CrossRef] [PubMed]

106. Choi, P.W.; Ng, S.W. The Functions of MicroRNA-200 Family in Ovarian Cancer: Beyond Epithelial-Mesenchymal Transition. Int. J. Mol. Sci. 2017, 18, 1207. [CrossRef] [PubMed] 
107. Han, X.; Zhen, S.; Ye, Z.; Lu, J.; Wang, L.; Li, P.; Li, J.; Zheng, X.; Li, H.; Chen, W.; et al. A Feedback Loop Between miR-30a/c-5p and DNMT1 Mediates Cisplatin Resistance in Ovarian Cancer Cells. Cell. Physiol. Biochem. 2017, 41, 973-986. [CrossRef] [PubMed]

108. Fan, Y.; Ma, X.; Li, H.; Gao, Y.; Huang, Q.; Zhang, Y.; Bao, X.; Du, Q.; Luo, G.; Liu, K.; et al. miR-122 promotes metastasis of clear-cell renal cell carcinoma by downregulating Dicer. Int. J. Cancer 2018, 142, 547-560. [CrossRef] [PubMed]

109. Liu, F.; Chen, N.; Xiao, R.; Wang, W.; Pan, Z. miR-144-3p serves as a tumor suppressor for renal cell carcinoma and inhibits its invasion and metastasis by targeting MAP3K8. Biochem. Biophys. Res. Commun. 2016, 480, 87-93. [CrossRef] [PubMed]

110. Machackova, T.; Mlcochova, H.; Stanik, M.; Dolezel, J.; Fedorko, M.; Pacik, D.; Poprach, A.; Svoboda, M.; Slaby, O. MiR-429 is linked to metastasis and poor prognosis in renal cell carcinoma by affecting epithelial-mesenchymal transition. Tumour Biol. 2016, 37, 14653-14658. [CrossRef] [PubMed]

111. Cao, J.; Liu, J.; Xu, R.; Zhu, X.; Liu, L.; Zhao, X. MicroRNA-21 stimulates epithelial-to-mesenchymal transition and tumorigenesis in clear cell renal cells. Mol. Med. Rep. 2016, 13, 75-82. [CrossRef] [PubMed]

112. Zhang, Y.; Cheng, X.; Liang, H.; Jin, Z. Long non-coding RNA HOTAIR and STAT3 synergistically regulate the cervical cancer cell migration and invasion. Chem. Biol. Interact. 2018, 286, 106-110. [CrossRef] [PubMed]

113. Meng, Y.; Li, Q.; Li, L.; Ma, R. The long non-coding RNA CRNDE promotes cervical cancer cell growth and metastasis. Biol. Chem. 2017, 399, 93-100. [CrossRef] [PubMed]

114. Dasgupta, P.; Kulkarni, P.; Majid, S.; Varahram, S.; Hashimoto, Y.; Bhat, N.S.; Shiina, M.; Deng, G.; Saini, S.; Tabatabai, Z.L.; et al. MicroRNA-203 inhibits long noncoding RNA HOTAIR and regulates tumorigenesis through epithelial-to-mesenchymal transition pathway in renal cell carcinoma. Mol. Cancer Ther. 2018, 17, 1061-1069. [CrossRef] [PubMed]

115. Li, J.; Huang, Y.; Deng, X.; Luo, M.; Wang, X.; Hu, H.; Liu, C.; Zhong, M. Long noncoding RNA H19 promotes transforming growth factor- $\beta$-induced epithelial-mesenchymal transition by acting as a competing endogenous RNA of miR-370-3p in ovarian cancer cells. Onco Targets Ther. 2018, 11, 427-440. [CrossRef] [PubMed]

116. Hong, Y.; He, H.; Sui, W.; Zhang, J.; Zhang, S.; Yang, D. Long non-coding RNA H1 promotes cell proliferation and invasion by acting as a ceRNA of miR-138 and releasing EZH2 in oral squamous cell carcinoma. Int. J. Oncol. 2018, 52, 901-912. [CrossRef] [PubMed]

117. Hu, D.; Shen, D.; Zhang, M.; Jiang, N.; Sun, F.; Yuan, S.; Wan, K. MiR-488 suppresses cell proliferation and invasion by targeting ADAM9 and lncRNA HULC in hepatocellular carcinoma. Am. J. Cancer Res. 2017, 7, 2070-2080. [PubMed]

118. Qiu, L.; Tang, Q.; Li, G.; Chen, K. Long non-coding RNAs as biomarkers and therapeutic targets: Recent insights into hepatocellular carcinoma. Life Sci. 2017, 191, 273-282. [CrossRef] [PubMed]

119. Tseng, J.H.; Bisogna, M.; Hoang, L.N.; Olvera, N.; Rodriguez-Aguayo, C.; Lopez-Berestein, G.; Sood, A.K.; Levine, D.A.; Jelinic, P. miR-200c-driven Mesenchymal-To-Epithelial Transition is a Therapeutic Target in Uterine Carcinosarcomas. Sci. Rep. 2017, 7, 3614. [CrossRef] [PubMed]

120. Zhou, W.; Ye, X.L.; Xu, J.; Cao, M.G.; Fang, Z.Y.; Li, L.Y.; Guan, G.H.; Liu, Q.; Qian, Y.H.; Xie, D. The lncRNA H19 mediates breast cancer cell plasticity during EMT and MET plasticity by differentially sponging miR-200b/c and let-7b. Sci. Signal. 2017, 10, eaak9557. [CrossRef] [PubMed]

121. Wang, L.; Yang, F.; Jia, L.T.; Yang, A.G. Missing Links in Epithelial-Mesenchymal Transition: Long Non-Coding RNAs Enter the Arena. Cell. Physiol. Biochem. 2017, 44, 1665-1680. [CrossRef] [PubMed]

122. Li, M.; Li, H.; Liu, X.; Xu, D.; Wang, F. MicroRNA-29b regulates TGF- $\beta 1$-mediated epithelial-mesenchymal transition of retinal pigment epithelial cells by targeting AKT2. Exp. Cell Res. 2016, 345, 115-124. [CrossRef] [PubMed]

123. Turcatel, G.; Rubin, N.; El-Hashash, A.; Warburton, D. MIR-99a and MIR-99b modulate TGF- $\beta$ induced epithelial to mesenchymal plasticity in normal murine mammary gland cells. PLoS ONE 2012, 7, e31032. [CrossRef] [PubMed]

124. Papadimitriou, E.; Vasilaki, E.; Vorvis, C.; Iliopoulos, D.; Moustakas, A.; Kardassis, D.; Stournaras, C. Differential regulation of the two RhoA-specific GEF isoforms Net1/Net1A by TGF- $\beta$ and miR-24: Role in epithelial-to-mesenchymal transition. Oncogene 2012, 31, 2862-2875. [CrossRef] [PubMed]

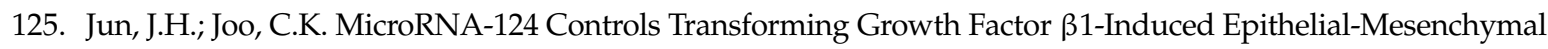
Transition in the Retinal Pigment Epithelium by Targeting RHOG. Investig. Ophthalmol. Vis. Sci. 2016, 57, $12-22$. 
126. Suzuki, T.; Mizutani, K.; Minami, A.; Nobutani, K.; Kurita, S.; Nagino, M.; Shimono, Y.; Takai, Y. Suppression of the TGF- $\beta 1$-induced protein expression of SNAI1 and N-cadherin by miR-199a. Genes Cells. 2014, 19, 667-675. [CrossRef] [PubMed]

127. Liu, B.; Sun, J.; Lei, X.; Zhu, Z.; Pei, C.; Qin, L. MicroRNA-486-5p suppresses TGF- $\beta_{2}$-induced proliferation, invasion and epithelial-mesenchymal transition of lens epithelial cells by targeting Smad2. J. Biosci. 2017, 42, 575-584. [CrossRef] [PubMed]

128. Guo, R.; Lv, Y.; Ouyang, Y.; Liu, S.; Li, D. The Role of miR-497/EIF3A Axis in TGF $\beta 1$-Induced Epithelial-Mesenchymal Transition and Extracellular Matrix in Rat Alveolar Epithelial Cells and Pulmonary Fibroblasts. J. Cell. Biochem. 2017, 118, 3401-3408. [CrossRef] [PubMed]

129. Zhang, H.W.; Wang, E.W.; Li, L.X.; Yi, S.H.; Li, L.C.; Xu, F.L.; Wang, D.L.; Wu, Y.Z.; Nian, W.Q. A regulatory loop involving miR-29c and Sp1 elevates the TGF- $\beta 1$ mediated epithelial-to-mesenchymal transition in lung cancer. Oncotarget 2016, 7, 85905-85916. [PubMed]

130. Li, D.P.; Fan, J.; Wu, Y.J.; Xie, Y.F.; Zha, J.M.; Zhou, X.M. MiR-155 up-regulated by TGF- $\beta$ promotes epithelial-mesenchymal transition, invasion and metastasis of human hepatocellular carcinoma cells in vitro. Am. J. Transl. Res. 2017, 9, 2956-2965. [PubMed]

131. Xu, M.; Wang, G.; Zhou, H.; Cai, J.; Li, P.; Zhou, M.; Lu, Y.; Jiang, X.; Huang, H.; Zhang, Y.; et al. TGF- $\beta 1-m i R-200 a-P T E N$ induces epithelial-mesenchymal transition and fibrosis of pancreatic stellate cells. Mol. Cell. Biochem. 2017, 431, 161-168. [CrossRef] [PubMed]

132. Qiao, B.; He, B.X.; Cai, J.H.; Tao, Q.; King-Yin Lam, A. MicroRNA-27a-3p Modulates the Wnt/ $\beta$-Catenin Signaling Pathway to Promote Epithelial-Mesenchymal Transition in Oral Squamous Carcinoma Stem Cells by Targeting SFRP1. Sci. Rep. 2017, 7, 44688. [CrossRef] [PubMed]

133. Jin, Y.; Wang, J.; Han, J.; Luo, D.; Sun, Z. MiR-122 inhibits epithelial-mesenchymal transition in hepatocellular carcinoma by targeting Snail1 and Snail2 and suppressing Wnt/ $\beta$-cadherin signaling pathway. Exp. Cell Res. 2017, 360, 210-217. [CrossRef] [PubMed]

134. Mao, X.W.; Xiao, J.Q.; Li, Z.Y.; Zheng, Y.C.; Zhang, N. Effects of microRNA-135a on the epithelial-mesenchymal transition, migration and invasion of bladder cancer cells by targeting GSK3 $\beta$ through the Wnt/ $\beta$-catenin signaling pathway. Exp. Mol. Med. 2018, 50, e429. [CrossRef] [PubMed]

135. Du, R.; Sun, W.; Xia, L.; Zhao, A.; Yu, Y.; Zhao, L.; Wang, H.; Huang, C.; Sun, S. Hypoxia-induced down-regulation of microRNA-34a promotes EMT by targeting the Notch signaling pathway in tubular epithelial cells. PLoS ONE 2012, 7, e30771. [CrossRef] [PubMed]

136. Katoh, Y.; Katoh, M. Hedgehog signaling, epithelial-to-mesenchymal transition and miRNA (review). Int. J. Mol. Med. 2008, 22, 271-275. [CrossRef] [PubMed]

137. Khanbabaei, H.; Teimoori, A.; Mohammadi, M. The interplay between microRNAs and Twist1 transcription factor: A systematic review. Tumour Biol. 2016, 37, 7007-7019. [CrossRef] [PubMed]

138. Kim, T.; Veronese, A.; Pichiorri, F.; Lee, T.J.; Jeon, Y.J.; Volinia, S.; Pineau, P.; Marchio, A.; Palatini, J.; Suh, S.S.; et al. p53 regulates epithelial-mesenchymal transition through microRNAs targeting ZEB1 and ZEB2. J. Exp. Med. 2011, 208, 875-883. [CrossRef] [PubMed]

139. Lagendijk, A.K.; Goumans, M.J.; Burkhard, S.B.; Bakkers, J. MicroRNA-23 restricts cardiac valve formation by inhibiting Has2 and extracellular hyaluronic acid production. Circ. Res. 2011, 109, 649-657. [CrossRef] [PubMed]

140. Bonet, F.; Dueñas, Á.; López-Sánchez, C.; García-Martínez, V.; Aránega, A.E.; Franco, D. MiR-23b and miR-199a impair epithelial-to-mesenchymal transition during atrioventricular endocardial cushion formation. Dev. Dyn. 2015, 244, 1259-1275. [CrossRef] [PubMed]

141. Stankunas, K.; Ma, G.K.; Kuhnert, F.J.; Kuo, C.J.; Chang, C.P. VEGF signaling has distinct spatiotemporal roles during heart valve development. Dev. Biol. 2010, 347, 325-336. [CrossRef] [PubMed]

142. Kumarswamy, R.; Mudduluru, G.; Ceppi, P.; Muppala, S.; Kozlowski, M.; Niklinski, J.; Papotti, M.; Allgayer, H. MicroRNA-30a inhibits epithelial-to-mesenchymal transition by targeting Snai1 and is downregulated in non-small cell lung cancer. Int. J. Cancer 2012, 130, 2044-2053. [CrossRef] [PubMed]

143. Ye, Z.; Zhao, L.; Li, J.; Chen, W.; Li, X. miR-30d Blocked Transforming Growth Factor $\beta 1$-Induced Epithelial-Mesenchymal Transition by Targeting Snail in Ovarian Cancer Cells. Int. J. Gynecol. Cancer 2015, 25, 1574-1581. [CrossRef] [PubMed] 
144. Dong, P.; Xiong, Y.; Watari, H.; Hanley, S.J.; Konno, Y.; Ihira, K.; Yamada, T.; Kudo, M.; Yue, J.; Sakuragi, N. MiR-137 and miR-34a directly target Snail and inhibit EMT, invasion and sphere-forming ability of ovarian cancer cells. J. Exp. Clin. Cancer Res. 2016, 35, 132. [CrossRef] [PubMed]

145. Zhang, J.P.; Zeng, C.; Xu, L.; Gong, J.; Fang, J.H.; Zhuang, S.M. MicroRNA-148a suppresses the epithelial-mesenchymal transition and metastasis of hepatoma cells by targeting Met/Snail signaling. Oncogene 2014, 33, 4069-4076. [CrossRef] [PubMed]

146. Xia, W.; Ma, X.; Li, X.; Dong, H.; Yi, J.; Zeng, W.; Yang, Z. miR-153 inhibits epithelial-to-mesenchymal transition in hepatocellular carcinoma by targeting Snail. Oncol. Rep. 2015, 34, 655-662. [CrossRef] [PubMed]

147. Liu, Z.; Long, J.; Du, R.; Ge, C.; Guo, K.; Xu, Y. miR-204 regulates the EMT by targeting snai1 to suppress the invasion and migration of gastric cancer. Tumour Biol. 2016, 37, 8327-8335. [CrossRef] [PubMed]

148. Zhang, X.; Zhang, T.; Yang, K.; Zhang, M.; Wang, K. miR-486-5p suppresses prostate cancer metastasis by targeting Snail and regulating epithelial-mesenchymal transition. Onco Targets Ther. 2016, 9, 6909-6914. [CrossRef] [PubMed]

149. Huang, Y.; Huang, H.; Li, M.; Zhang, X.; Liu, Y.; Wang, Y. MicroRNA-374c-5p regulates the invasion and migration of cervical cancer by acting on the Foxc1/snail pathway. Biomed. Pharmacother. 2017, 94, 1038-1047. [CrossRef] [PubMed]

150. Xu, X.; Zhu, Y.; Liang, Z.; Li, S.; Xu, X.; Wang, X.; Wu, J.; Hu, Z.; Meng, S.; Liu, B.; et al. c-Met and CREB1 are involved in miR-433-mediated inhibition of the epithelial-mesenchymal transition in bladder cancer by regulating Akt/GSK-3 $\beta /$ Snail signaling. Cell Death Dis. 2016, 7, e2088. [CrossRef] [PubMed]

151. Zhang, Z.; Zhang, M.; Chen, Q.; Zhang, Q. Downregulation of microRNA-145 promotes epithelial-mesenchymal transition via regulating Snail in osteosarcoma. Cancer Gene Ther. 2017, 24, 83-88. [CrossRef] [PubMed]

152. Kwak, S.Y.; Yoo, J.O.; An, H.J.; Bae, I.H.; Park, M.J.; Kim, J.; Han, Y.H. miR-5003-3p promotes epithelial-mesenchymal transition in breast cancer cells through Snail stabilization and direct targeting of E-cadherin. J. Mol. Cell Biol. 2016, 8, 372-383. [CrossRef] [PubMed]

153. Chang, C.W.; Yu, J.C.; Hsieh, Y.H.; Yao, C.C.; Chao, J.I.; Chen, P.M.; Hsieh, H.Y.; Hsiung, C.N.; $\mathrm{Chu}, \mathrm{H} . W . ;$ Shen, C.Y.; et al. MicroRNA-30a increases tight junction protein expression to suppress the epithelial-mesenchymal transition and metastasis by targeting Slug in breast cancer. Oncotarget 2016, 7, 16462-16478. [CrossRef] [PubMed]

154. Wu, Z.; Li, X.; Cai, X.; Huang, C.; Zheng, M. miR-497 inhibits epithelial mesenchymal transition in breast carcinoma by targeting Slug. Tumour Biol. 2016, 37, 7939-7950. [CrossRef] [PubMed]

155. Qiu, Y.H.; Wei, Y.P.; Shen, N.J.; Wang, Z.C.; Kan, T.; Yu, W.L.; Yi, B.; Zhang, Y.J. miR-204 inhibits epithelial to mesenchymal transition by targeting slug in intrahepatic cholangiocarcinoma cells. Cell. Physiol. Biochem. 2013, 32, 1331-1341. [CrossRef] [PubMed]

156. Chen, W.X.; Zhang, Z.G.; Ding, Z.Y.; Liang, H.F.; Song, J.; Tan, X.L.; Wu, J.J.; Li, G.Z.; Zeng, Z.; Zhang, B.X.; et al. MicroRNA-630 suppresses tumor metastasis through the TGF- $\beta$-miR-630-Slug signaling pathway and correlates inversely with poor prognosis in hepatocellular carcinoma. Oncotarget 2016, 7, 22674-22686. [CrossRef] [PubMed]

157. Liao, H.; Bai, Y.; Qiu, S.; Zheng, L.; Huang, L.; Liu, T.; Wang, X.; Liu, Y.; Xu, N.; Yan, X.; et al. MiR-203 downregulation is responsible for chemoresistance in human glioblastoma by promoting epithelial-mesenchymal transition via SNAI2. Oncotarget 2015, 6, 8914-8928. [CrossRef] [PubMed]

158. Li, W.; Jiang, G.; Zhou, J.; Wang, H.; Gong, Z.; Zhang, Z.; Min, K.; Zhu, H.; Tan, Y. Down-regulation of miR-140 induces EMT and promotes invasion by targeting Slug in esophageal cancer. Cell. Physiol. Biochem. 2014, 34, 1466-1476. [CrossRef] [PubMed]

159. Xu, M.; Li, J.; Wang, X.; Meng, S.; Shen, J.; Wang, S.; Xu, X.; Xie, B.; Liu, B.; Xie, L. MiR-22 suppresses epithelial-mesenchymal transition in bladder cancer by inhibiting Snail and MAPK1/Slug/vimentin feedback loop. Cell Death Dis. 2018, 9, 209. [CrossRef] [PubMed]

160. Zheng, M.; Jiang, Y.P.; Chen, W.; Li, K.D.; Liu, X.; Gao, S.Y.; Feng, H.; Wang, S.S.; Jiang, J.; Ma, X.R.; et al. Snail and Slug collaborate on EMT and tumor metastasis through miR-101-mediated EZH2 axis in oral tongue squamous cell carcinoma. Oncotarget 2015, 6, 6797-6810. [CrossRef] [PubMed]

161. Siemens, H.; Jackstadt, R.; Hünten, S.; Kaller, M.; Menssen, A.; Götz, U.; Hermeking, H. miR-34 and SNAIL form a double-negative feedback loop to regulate epithelial-mesenchymal transitions. Cell Cycle 2011, 10, 4256-4271. [CrossRef] [PubMed] 
162. Hahn, S.; Jackstadt, R.; Siemens, H.; Hünten, S.; Hermeking, H. SNAIL and miR-34a feed-forward regulation of ZNF281/ZBP99 promotes epithelial-mesenchymal transition. EMBO J. 2013, 32, 3079-3095. [CrossRef] [PubMed]

163. Chang, T.H.; Tsai, M.F.; Gow, C.H.; Wu, S.G.; Liu, Y.N.; Chang, Y.L.; Yu, S.L.; Tsai, H.C.; Lin, S.W.; Chen, Y.W.; et al. Upregulation of microRNA-137 expression by Slug promotes tumor invasion and metastasis of non-small cell lung cancer cells through suppression of TFAP2C. Cancer Lett. 2017, 402, 190-202. [CrossRef] [PubMed]

164. Kim, M.; Jang, K.; Miller, P.; Picon-Ruiz, M.; Yeasky, T.M.; El-Ashry, D.; Slingerland, J.M. VEGFA links self-renewal and metastasis by inducing Sox2 to repress miR-452, driving Slug. Oncogene 2017, 36, 5199-5211. [CrossRef] [PubMed]

165. Findlay, V.J.; Wang, C.; Nogueira, L.M.; Hurst, K.; Quirk, D.; Ethier, S.P.; Staveley O'Carroll, K.F.; Watson, D.K.; Camp, E.R. SNAI2 modulates colorectal cancer 5-fluorouracil sensitivity through miR145 repression. Mol. Cancer Ther. 2014, 13, 2713-2726. [CrossRef] [PubMed]

166. Moes, M.; Le Béchec, A.; Crespo, I.; Laurini, C.; Halavatyi, A.; Vetter, G.; Del Sol, A.; Friederich, E. A novel network integrating a miRNA-203/SNAI1 feedback loop which regulates epithelial to mesenchymal transition. PLoS ONE 2012, 7, e35440. [CrossRef] [PubMed]

167. Zhan, Y.; Li, X.; Liang, X.; Li, L.; Cao, B.; Wang, B.; Ma, J.; Ding, F.; Wang, X.; Pang, D.; et al. MicroRNA-182 drives colonization and macroscopic metastasis via targeting its suppressor SNAI1 in breast cancer. Oncotarget 2017, 8, 4629-4641. [CrossRef] [PubMed]

168. Liu, Y.N.; Yin, J.J.; Abou-Kheir, W.; Hynes, P.G.; Casey, O.M.; Fang, L.; Yi, M.; Stephens, R.M.; Seng, V.; Sheppard-Tillman, H.; et al. MiR-1 and miR-200 inhibit EMT via Slug-dependent and tumorigenesis via Slug-independent mechanisms. Oncogene 2013, 32, 296-306. [CrossRef] [PubMed]

169. Ding, X.; Park, S.I.; McCauley, L.K.; Wang, C.Y. Signaling between transforming growth factor $\beta$ (TGF- $\beta$ ) and transcription factor SNAI2 represses expression of microRNA miR-203 to promote epithelial-mesenchymal transition and tumor metastasis. J. Biol. Chem. 2013, 288, 10241-10253. [CrossRef] [PubMed]

170. Zhou, H.; Huang, Z.; Chen, X.; Chen, S. miR-98 inhibits expression of TWIST to prevent progression of non-small cell lung cancers. Biomed. Pharmacother. 2017, 89, 1453-1461. [CrossRef] [PubMed]

171. Wang, T.; Hou, J.; Li, Z.; Zheng, Z.; Wei, J.; Song, D.; Hu, T.; Wu, Q.; Yang, J.Y.; Cai, J.C. miR-15a-3p and miR-16-1-3p Negatively Regulate Twist1 to Repress Gastric Cancer Cell Invasion and Metastasis. Int. J. Biol. Sci. 2017, 13, 122-134. [CrossRef] [PubMed]

172. Wang, J.; Wang, X.; Liu, F.; Fu, Y. microRNA-335 inhibits colorectal cancer HCT116 cells growth and epithelial-mesenchymal transition (EMT) process by targeting Twist1. Pharmazie 2017, 72, 475-481. [PubMed]

173. Liu, S.; Cui, J.; Liao, G.; Zhang, Y.; Ye, K.; Lu, T.; Qi, J.; Wan, G. MiR-137 regulates epithelial-mesenchymal transition in gastrointestinal stromal tumor. Tumour Biol. 2014, 35, 9131-9138. [CrossRef] [PubMed]

174. Zhao, N.; Sun, H.; Sun, B.; Zhu, D.; Zhao, X.; Wang, Y.; Gu, Q.; Dong, X.; Liu, F.; Zhang, Y.; et al. miR-27a-3p suppresses tumor metastasis and VM by down-regulating VE-cadherin expression and inhibiting EMT: An essential role for Twist-1 in HCC. Sci. Rep. 2016, 6, 23091. [CrossRef] [PubMed]

175. Dong, P.; Kaneuchi, M.; Watari, H.; Sudo, S.; Sakuragi, N. MicroRNA-106b modulates epithelial-mesenchymal transition by targeting TWIST1 in invasive endometrial cancer cell lines. Mol. Carcinog. 2014, 53, 349-359. [CrossRef] [PubMed]

176. Zhu, X.; Shen, H.; Yin, X.; Long, L.; Xie, C.; Liu, Y.; Hui, L.; Lin, X.; Fang, Y.; Cao, Y.; et al. miR-186 regulation of Twist1 and ovarian cancer sensitivity to cisplatin. Oncogene 2016, 35, 323-332. [CrossRef] [PubMed]

177. Zhao, X.; Wang, Y.; Deng, R.; Zhang, H.; Dou, J.; Yuan, H.; Hou, G.; Du, Y.; Chen, Q.; Yu, J. miR-186 suppresses prostate cancer progression by targeting Twist1. Oncotarget 2016, 7, 33136-33151. [PubMed]

178. Yu, J.; Xie, F.; Bao, X.; Chen, W.; Xu, Q. miR-300 inhibits epithelial to mesenchymal transition and metastasis by targeting Twist in human epithelial cancer. Mol. Cancer 2014, 13, 121. [CrossRef] [PubMed]

179. Wang, R.; Li, Y.; Hou, Y.; Yang, Q.; Chen, S.; Wang, X.; Wang, Z.; Yang, Y.; Chen, C.; Wang, Z.; et al. The PDGF-D/miR-106a/Twist1 pathway orchestrates epithelial-mesenchymal transition in gemcitabine resistance hepatoma cells. Oncotarget 2015, 6, 7000-7010. [CrossRef] [PubMed]

180. Zhang, M.; Gong, W.; Zuo, B.; Chu, B.; Tang, Z.; Zhang, Y.; Yang, Y.; Zhou, D.; Weng, M.; Qin, Y.; et al. The microRNA miR-33a suppresses IL-6-induced tumor progression by binding Twist in gallbladder cancer. Oncotarget 2016, 7, 78640-78652. [CrossRef] [PubMed] 
181. Chen, D.; Dang, B.L.; Huang, J.Z.; Chen, M.; Wu, D.; Xu, M.L.; Li, R.; Yan, G.R. MiR-373 drives the epithelial-to-mesenchymal transition and metastasis via the miR-373-TXNIP-HIF1 $\alpha$-TWIST signaling axis in breast cáncer. Oncotarget 2015, 6, 32701-32712. [PubMed]

182. Yu, Y.; Zhao, Y.; Sun, X.H.; Ge, J.; Zhang, B.; Wang, X.; Cao, X.C. Down-regulation of miR-129-5p via the Twist1-Snail feedback loop stimulates the epithelial-mesenchymal transition and is associated with poor prognosis in breast cancer. Oncotarget 2015, 6, 34423-34436. [CrossRef] [PubMed]

183. Wei, W.F.; Zhou, C.F.; Wu, X.G.; He, L.N.; Wu, L.F.; Chen, X.J.; Yan, R.M.; Zhong, M.; Yu, Y.H.; Liang, L.; et al. MicroRNA-221-3p, a TWIST2 target, promotes cervical cancer metastasis by directly targeting THBS2. Cell Death Dis. 2017, 8, 3220. [CrossRef] [PubMed]

184. Drasin, D.J.; Guarnieri, A.L.; Neelakantan, D.; Kim, J.; Cabrera, J.H.; Wang, C.A.; Zaberezhnyy, V.; Gasparini, P.; Cascione, L.; Huebner, K.; et al. TWIST1-Induced miR-424 Reversibly Drives Mesenchymal Programming while Inhibiting Tumor Initiation. Cancer Res. 2015, 75, 1908-1921. [CrossRef] [PubMed]

185. Dong, P.; Karaayvaz, M.; Jia, N.; Kaneuchi, M.; Hamada, J.; Watari, H.; Sudo, S.; Ju, J.; Sakuragi, N. Mutant p53 gain-of-function induces epithelial-mesenchymal transition through modulation of the miR-130b-ZEB1 axis. Oncogene 2013, 32, 3286-3295. [CrossRef] [PubMed]

186. Al-Khalaf, H.H.; Aboussekhra, A. MicroRNA-141 and microRNA-146b-5p inhibit the prometastatic mesenchymal characteristics through the RNA-binding protein AUF1 targeting the transcription factor ZEB1 and the protein kinase AKT. J. Biol. Chem. 2014, 289, 31433-31447. [CrossRef] [PubMed]

187. Zhou, W.; Thiery, J.P. Loss of Git2 induces epithelial-mesenchymal transition by miR146a-Cnot6L-controlled expression of Zeb1. J. Cell Sci. 2013, 126, 2740-2746. [CrossRef] [PubMed]

188. Asakura, T.; Yamaguchi, N.; Ohkawa, K.; Yoshida, K. Proteasome inhibitor-resistant cells cause EMT-induction via suppression of E-cadherin by miR-200 and ZEB1. Int. J. Oncol. 2015, 46, 2251-2260. [CrossRef] [PubMed]

189. Filios, S.R.; Xu, G.; Chen, J.; Hong, K.; Jing, G.; Shalev, A. MicroRNA-200 is induced by thioredoxin-interacting protein and regulates Zeb1 protein signaling and beta cell apoptosis. J. Biol. Chem. 2014, 289, 36275-36283. [CrossRef] [PubMed]

190. Guo, L.; Chen, C.; Shi, M.; Wang, F.; Chen, X.; Diao, D.; Hu, M.; Yu, M.; Qian, L.; Guo, N. Stat3-coordinated Lin-28-let-7-HMGA2 and miR-200-ZEB1 circuits initiate and maintain oncostatin M-driven epithelial-mesenchymal transition. Oncogene 2013, 32, 5272-5282. [CrossRef] [PubMed]

191. Grassian, A.R.; Lin, F.; Barrett, R.; Liu, Y.; Jiang, W.; Korpal, M.; Astley, H.; Gitterman, D.; Henley, T.; Howes, R.; et al. Isocitrate dehydrogenase (IDH) mutations promote a reversible ZEB1/microRNA (miR)-200-dependent epithelial-mesenchymal transition (EMT). J. Biol. Chem. 2012, 287, 42180-42194. [CrossRef] [PubMed]

192. Xiong, M.; Jiang, L.; Zhou, Y.; Qiu, W.; Fang, L.; Tan, R.; Wen, P.; Yang, J. The miR-200 family regulates TGF- $\beta 1$-induced renal tubular epithelial to mesenchymal transition through Smad pathway by targeting ZEB1 and ZEB2 expression. Am. J. Physiol. Ren. Physiol. 2012, 302, F369-F379. [CrossRef] [PubMed]

193. Gregory, P.A.; Bert, A.G.; Paterson, E.L.; Barry, S.C.; Tsykin, A.; Farshid, G.; Vadas, M.A.; Khew-Goodall, Y.; Goodall, G.J. The miR-200 family and miR-205 regulate epithelial to mesenchymal transition by targeting ZEB1 and SIP1. Nat. Cell Biol. 2008, 10, 593-601. [CrossRef] [PubMed]

194. Tang, W.B.; Zheng, L.; Yan, R.; Yang, J.; Ning, J.; Peng, L.; Zhou, Q.; Chen, L. miR302a-3p May Modulate Renal Epithelial-Mesenchymal Transition in Diabetic Kidney Disease by Targeting ZEB1. Nephron 2018, 138, 231-242. [CrossRef] [PubMed]

195. Wu, C.W.; Peng, M.L.; Yeh, K.T.; Tsai, Y.Y.; Chiang, C.C.; Cheng, Y.W. Inactivation of p53 in pterygium influence miR-200a expression resulting in ZEB1/ZEB2 up-regulation and EMT processing. Exp. Eye Res. 2016, 146, 206-211. [CrossRef] [PubMed]

196. Díaz-López, A.; Díaz-Martín, J.; Moreno-Bueno, G.; Cuevas, E.P.; Santos, V.; Olmeda, D.; Portillo, F.; Palacios, J.; Cano, A. Zeb1 and Snail1 engage miR-200f transcriptional and epigenetic regulation during EMT. Int. J. Cancer 2015, 136, E62-E73. [CrossRef] [PubMed]

197. Qu, J.; Li, M.; An, J.; Zhao, B.; Zhong, W.; Gu, Q.; Cao, L.; Yang, H.; Hu, C. MicroRNA-33b inhibits lung adenocarcinoma cell growth, invasion, and epithelial-mesenchymal transition by suppressing Wnt/ $\beta$-catenin/ZEB1 signaling. Int. J. Oncol. 2015, 47, 2141-2152. [CrossRef] [PubMed]

198. Jiang, R.; Zhang, C.; Liu, G.; Gu, R.; Wu, H. MicroRNA-126 Inhibits Proliferation, Migration, Invasion, and EMT in Osteosarcoma by Targeting ZEB1. J. Cell. Biochem. 2017, 118, 3765-3774. [CrossRef] [PubMed] 
199. Zhao, L.; Li, R.; Xu, S.; Li, Y.; Zhao, P.; Dong, W.; Liu, Z.; Zhao, Q.; Tan, B. Tumor suppressor miR-128-3p inhibits metastasis and epithelial-mesenchymal transition by targeting ZEB1 in esophageal squamous-cell cancer. Acta Biochim. Biophys. Sin. 2018, 50, 171-180. [CrossRef] [PubMed]

200. Jin, M.; Yang, Z.; Ye, W.; Xu, H.; Hua, X. MicroRNA-150 predicts a favorable prognosisin patients with epithelial ovarian cancer, and inhibits cell invasion and metastasis by suppressing transcriptional repressor ZEB1. PLOS ONE 2014, 9, e103965.

201. Chung, V.Y.; Tan, T.Z.; Tan, M.; Wong, M.K.; Kuay, K.T.; Yang, Z.; Ye, J.; Muller, J.; Koh, C.M.; Guccione, E.; et al. GRHL2-miR-200-ZEB1 maintains the epithelial status of ovarian cancer through transcriptional regulation and histone modification. Sci. Rep. 2016, 6, 19943. [CrossRef] [PubMed]

202. Bai, W.D.; Ye, X.M.; Zhang, M.Y.; Zhu, H.Y.; Xi, W.J.; Huang, X.; Zhao, J.; Gu, B.; Zheng, G.X.; Yang, A.G.; et al. MiR-200c suppresses TGF- $\beta$ signaling and counteracts trastuzumab resistance and metastasis by targeting ZNF217 and ZEB1 in breast cancer. Int. J. Cancer 2014, 135, 1356-1368. [CrossRef] [PubMed]

203. Zhao, W.; Wang, H.; Han, X.; Ma, J.; Zhou, Y.; Chen, Z.; Zhou, H.; Xu, H.; Sun, Z.; Kong, B.; et al. $\Delta N p 63 \alpha$ attenuates tumor aggressiveness by suppressing miR-205/ZEB1-mediated epithelial-mesenchymal transition in cervical squamous cell carcinoma. Tumour Biol. 2016, 37, 10621-10632. [CrossRef] [PubMed]

204. Wang, Y.; Dong, X.; Hu, B.; Wang, X.J.; Wang, Q.; Wang, W.L. The effects of Micro-429 on inhibition of cervical cancer cells through targeting ZEB1 and CRKL. Biomed. Pharmacother. 2016, 80, 311-321. [CrossRef] [PubMed]

205. Hu, Y.; Xie, H.; Liu, Y.; Liu, W.; Liu, M.; Tang, H. miR-484 suppresses proliferation and epithelial-mesenchymal transition by targeting ZEB1 and SMAD2 in cervical cancer cells. Cancer Cell Int. 2017, 17, 36. [CrossRef] [PubMed]

206. Deng, S.; Li, X.; Niu, Y.; Zhu, S.; Jin, Y.; Deng, S.; Chen, J.; Liu, Y.; He, C.; Yin, T.; et al. MiR-652 inhibits acidic microenvironment-induced epithelial-mesenchymal transition of pancreatic cancer cells by targeting ZEB1. Oncotarget 2015, 6, 39661-39675. [CrossRef] [PubMed]

207. El Bezawy, R.; Cominetti, D.; Fenderico, N.; Zuco, V.; Beretta, G.L.; Dugo, M.; Arrighetti, N.; Stucchi, C.; Rancati, T.; Valdagni, R.; et al. miR-875-5p counteracts epithelial-to-mesenchymal transition and enhances radiation response in prostate cancer through repression of the EGFR-ZEB1 axis. Cancer Lett. 2017, 395, 53-62. [CrossRef] [PubMed]

208. Majid, S.; Dar, A.A.; Saini, S.; Deng, G.; Chang, I.; Greene, K.; Tanaka, Y.; Dahiya, R.; Yamamura, S. MicroRNA-23b functions as a tumor suppressor by regulating Zeb1 in bladder cancer. PLoS ONE 2013, 8, e67686. [CrossRef] [PubMed]

209. Chen, W.; Kong, K.K.; Xu, X.K.; Chen, C.; Li, H.; Wang, F.Y.; Peng, X.F.; Zhang, Z.; Li, P.; Li, J.L.; et al. Downregulation of miR-205 is associated with glioblastoma cell migration, invasion, and the epithelial-mesenchymal transition, by targeting ZEB1 via the Akt/mTOR signaling pathway. Int. J. Oncol. 2018, 52, 485-495. [CrossRef] [PubMed]

210. Chandra Mangalhara, K.; Manvati, S.; Saini, S.K.; Ponnusamy, K.; Agarwal, G.; Abraham, S.K.; Bamezai, R.N.K. ERK2-ZEB1-miR-101-1 axis contributes to epithelial-mesenchymal transition and cell migration in cancer. Cancer Lett. 2017, 391, 59-73. [CrossRef] [PubMed]

211. Barbáchano, A.; Fernández-Barral, A.; Pereira, F.; Segura, M.F.; Ordóñez-Morán, P.; Carrillo-de Santa Pau, E.; González-Sancho, J.M.; Hanniford, D.; Martínez, N.; Costales-Carrera, A.; et al. SPROUTY-2 represses the epithelial phenotype of colon carcinoma cells via upregulation of ZEB1 mediated by ETS1 and miR-200/miR-150. Oncogene 2016, 35, 2991-3003. [CrossRef] [PubMed]

212. Ungewiss, C.; Rizvi, Z.H.; Roybal, J.D.; Peng, D.H.; Gold, K.A.; Shin, D.H.; Creighton, C.J.; Gibbons, D.L. The microRNA-200/Zeb1 axis regulates ECM-dependent $\beta 1$-integrin/FAK signaling, cancer cell invasion and metastasis through CRKL. Sci. Rep. 2016, 6, 18652. [CrossRef] [PubMed]

213. Teng, Y.; Mei, Y.; Hawthorn, L.; Cowell, J.K. WASF3 regulates miR-200 inactivation by ZEB1 through suppression of KISS1 leading to increased invasiveness in breast cancer cells. Oncogene 2014, 33, $203-211$. [CrossRef] [PubMed]

214. Selth, L.A.; Das, R.; Townley, S.L.; Coutinho, I.; Hanson, A.R.; Centenera, M.M.; Stylianou, N.; Sweeney, K.; Soekmadji, C.; Jovanovic, L.; et al. A ZEB1-miR-375-YAP1 pathway regulates epithelial plasticity in prostate cancer. Oncogene 2017, 36, 24-34. [CrossRef] [PubMed] 
215. Zheng, Y.B.; Luo, H.P.; Shi, Q.; Hao, Z.N.; Ding, Y.; Wang, Q.S.; Li, S.B.; Xiao, G.C.; Tong, S.L. miR-132 inhibits colorectal cancer invasion and metastasis via directly targeting ZEB2. World J. Gastroenterol. 2014, 20, 6515-6522. [CrossRef] [PubMed]

216. You, J.; Li, Y.; Fang, N.; Liu, B.; Zu, L.; Chang, R.; Li, X.; Zhou, Q. MiR-132 suppresses the migration and invasion of lung cancer cells via targeting the EMT regulator ZEB2. PLoS ONE 2014, 9, e91827. [CrossRef] [PubMed]

217. Zhou, J.; Xie, M.; Shi, Y.; Luo, B.; Gong, G.; Li, J.; Wang, J.; Zhao, W.; Zi, Y.; Wu, X.; et al. MicroRNA-153 functions as a tumor suppressor by targeting SET7 and ZEB2 in ovarian cancer cells. Oncol. Rep. 2015, 34, 111-120. [CrossRef] [PubMed]

218. Lin, X.; Yang, Z.; Zhang, P.; Liu, Y.; Shao, G. miR-154 inhibits migration and invasionof human non-small cell lung cancer by targeting ZEB2. Oncol. Lett. 2016, 12, 301-306. [CrossRef] [PubMed]

219. Duan, X.; Fu, Z.; Gao, L.; Zhou, J.; Deng, X.; Luo, X.; Fang, W.; Luo, R. Direct interaction between miR-203 and ZEB2 suppresses epithelial-mesenchymal transition signaling and reduces lung adenocarcinoma chemoresistance. Acta Biochim. Biophys. Sin. 2016, 48, 1042-1049. [CrossRef] [PubMed]

220. Jiang, Q.; Zhou, Y.; Yang, H.; Li, L.; Deng, X.; Cheng, C.; Xie, Y.; Luo, X.; Fang, W.; Liu, Z. Adirectly negative interaction of miR-203 and ZEB2 modulates tumor stemness and chemotherapy resistance in nasopharyngeal carcinoma. Oncotarget 2016, 7, 67288-67301. [CrossRef] [PubMed]

221. Huang, N.; Wu, Z.; Lin, L.; Zhou, M.; Wang, L.; Ma, H.; Xia, J.; Bin, J.; Liao, Y.; Liao, W. MiR-338-3p inhibits epithelial-mesenchymal transition in gastric cancer cells by targeting ZEB2 and MACC1/Met/Akt signaling. Oncotarget 2015, 6, 15222-15234. [CrossRef] [PubMed]

222. Li, J.; Yuan, J.; Yuan, X.; Zhao, J.; Zhang, Z.; Weng, L.; Liu, J. MicroRNA-200b inhibits the growth and metastasis of glioma cells via targeting ZEB2. Int. J. Oncol. 2016, 48, 541-550. [CrossRef] [PubMed]

223. Kurashige, J.; Kamohara, H.; Watanabe, M.; Hiyoshi, Y.; Iwatsuki, M.; Tanaka, Y.; Kinoshita, K.; Saito, S.; Baba, Y.; Baba, H. MicroRNA-200b regulates cell proliferation, invasion, and migration by directly targeting ZEB2 in gastric carcinoma. Ann. Surg. Oncol. 2012, 19, S656-S664. [CrossRef] [PubMed]

224. Li, H.; Xu, L.; Li, C.; Zhao, L.; Ma, Y.; Zheng, H.; Li, Z.; Zhang, Y.; Wang, R.; Liu, Y.; et al. Ubiquitin ligase Cbl-b represses IGF-I-induced epithelial mesenchymal transition via ZEB2 and microRNA-200c regulation in gastric cancer cells. Mol. Cancer 2014, 13, 136. [CrossRef] [PubMed]

225. Jiao, A.; Sui, M.; Zhang, L.; Sun, P.; Geng, D.; Zhang, W.; Wang, X.; Li, J. MicroRNA-200c inhibits the metastasis of non-small cell lung cancer cells by targeting ZEB2, anepithelial-mesenchymal transition regulator. Mol. Med. Rep. 2016, 13, 3349-3355. [CrossRef] [PubMed]

226. Liu, Y.; Sánchez-Tilló, E.; Lu, X.; Huang, L.; Clem, B.; Telang, S.; Jenson, A.B.; Cuatrecasas, M.; Chesney, J.; Postigo, A.; et al. The ZEB1 transcription factor acts in a negative feedback loop with miR200 downstream of Ras and Rb1 to regulate Bmi1 expression. J. Biol. Chem. 2014, 289, 4116-4125. [CrossRef] [PubMed]

227. Burk, U.; Schubert, J.; Wellner, U.; Schmalhofer, O.; Vincan, E.; Spaderna, S.; Brabletz, T. A reciprocal repression between ZEB1 and members of the miR-200 family promotes EMT and invasion in cancer cells. EMBO Rep. 2008, 9, 582-589. [CrossRef] [PubMed]

228. Diepenbruck, M.; Tiede, S.; Saxena, M.; Ivanek, R.; Kalathur, R.K.R.; Lüönd, F.; Meyer-Schaller, N.; Christofori, G. miR-1199-5p and Zeb1 function in a double-negative feedback loop potentially coordinating EMT and tumour metastasis. Nat. Commun. 2017, 8, 1168. [CrossRef] [PubMed]

229. Hou, L.K.; Yu, Y.; Xie, Y.G.; Wang, J.; Mao, J.F.; Zhang, B.; Wang, X.; Cao, X.C. miR-340 and ZEB1 negative feedback loop regulates TGF- $\beta$ - mediated breast cancer progression. Oncotarget 2016, 7, 26016-26026. [CrossRef] [PubMed]

230. Ren, D.; Wang, M.; Guo, W.; Huang, S.; Wang, Z.; Zhao, X.; Du, H.; Song, L.; Peng, X. Double-negative feedback loop between ZEB2 and miR-145 regulates epithelial-mesenchymal transition and stem cell properties in prostate cáncer cells. Cell Tissue Res. 2014, 358, 763-778. [CrossRef] [PubMed]

231. Guo, F.; Cogdell, D.; Hu, L.; Yang, D.; Sood, A.K.; Xue, F.; Zhang, W. MiR-101 suppresses the epithelial-to-mesenchymal transition by targeting ZEB1 and ZEB2 in ovarian carcinoma. Oncol. Rep. 2014, 31, 2021-2028. [CrossRef] [PubMed]

232. Korpal, M.; Lee, E.S.; Hu, G.; Kang, Y. The miR-200 family inhibits epithelial-mesenchymal transition and cancer cell migration by direct targeting of E-cadherin transcriptional repressors ZEB1 and ZEB2. J. Biol. Chem. 2008, 283, 14910-14914. [CrossRef] [PubMed] 
233. Park, S.M.; Gaur, A.B.; Lengyel, E.; Peter, M.E. The miR-200 family determines the epithelial phenotype of cancer cells by targeting the E-cadherin repressors ZEB1 and ZEB2. Genes Dev. 2008, 22, 894-907. [CrossRef] [PubMed]

234. Cong, N.; Du, P.; Zhang, A.; Shen, F.; Su, J.; Pu, P.; Wang, T.; Zjang, J.; Kang, C.; Zhang, Q. Downregulated microRNA-200a promotes EMT and tumor growth through the Wnt/ $\beta$-catenin pathway by targeting the E-cadherin repressors ZEB1/ZEB2 in gastric adenocarcinoma. Oncol. Rep. 2013, 29, 1579-1587. [CrossRef] [PubMed]

235. Eggers, J.C.; Martino, V.; Reinbold, R.; Schäfer, S.D.; Kiesel, L.; Starzinski-Powitz, A.; Schüring, A.N.; Kemper, B.; Greve, B.; Götte, M. microRNA miR-200b affects proliferation, invasiveness and stemness of endometriotic cells by targeting ZEB1, ZEB2 and KLF4. Reprod. Biomed. Online 2016, 32, 434-445. [CrossRef] [PubMed]

236. Qiu, G.; Lin, Y.; Zhang, H.; Wu, D. miR-139-5p inhibits epithelial-mesenchymal transition, migration and invasion of hepatocellular carcinoma cells by targeting ZEB1 and ZEB2. Biochem. Biophys. Res. Commun. 2015, 463, 315-321. [CrossRef] [PubMed]

237. Lee, J.Y.; Park, M.K.; Park, J.H.; Lee, H.J.; Shin, D.H.; Kang, Y.; Lee, C.H.; Kong, G. Loss of the polycomb protein Mel-18 enhances the epithelial-mesenchymal transition by ZEB1 and ZEB2 expression through the downregulation of miR-205 in breast cancer. Oncogene 2014, 33, 1325-1335. [CrossRef] [PubMed]

238. Ma, P.; Ni, K.; Ke, J.; Zhang, W.; Feng, Y.; Mao, Q. miR-448 inhibits the epithelial-mesenchymal transition in breast cancer cells by directly targeting the E-cadherin repressor ZEB1/2. Exp. Biol. Med. 2018, 243, 473-480. [CrossRef] [PubMed]

239. Pang, H.; Zheng, Y.; Zhao, Y.; Xiu, X.; Wang, J. miR-590-3p suppresses cancer cell migration, invasion and epithelial-mesenchymal transition in glioblastoma multiforme by targeting ZEB1 and ZEB2. Biochem. Biophys. Res. Commun. 2015, 468, 739-745. [CrossRef] [PubMed]

240. Liu, H.; Wang, H.; Liu, X.; Yu, T. miR-1271 inhibits migration, invasion and epithelial-mesenchymal transition by targeting ZEB1 and TWIST1 in pancreatic cancer cells. Biochem. Biophys. Res. Commun. 2016, 472, 346-352. [CrossRef] [PubMed]

241. Shi, Z.M.; Wang, L.; Shen, H.; Jiang, C.F.; Ge, X.; Li, D.M.; Wen, Y.Y.; Sun, H.R.; Pan, M.H.; Li, W.; et al. Downregulation of miR-218 contributes to epithelial-mesenchymal transition and tumor metastasis in lung cancer by targeting Slug/ZEB2 signaling. Oncogene 2017, 36, 2577-2588. [CrossRef] [PubMed]

242. Shan, Y.; Zhang, L.; Bao, Y.; Li, B.; He, C.; Gao, M.; Feng, X.; Xu, W.; Zhang, X.; Wang, S. Epithelial-mesenchymal transition, a novel target of sulforaphane via COX-2/MMP2,9/Snail, ZEB1 and miR-200c/ZEB1 pathways in human bladder cancer cells. J. Nutr. Biochem. 2013, 24, 1062-1069. [CrossRef] [PubMed]

243. Wang, S.C.; Lin, X.L.; Li, J.; Zhang, T.T.; Wang, H.Y.; Shi, J.W.; Yang, S.; Zhao, W.T.; Xie, R.Y.; Wei, F.; et al. MicroRNA-122 triggers mesenchymal-epithelial transition and suppresses hepatocellular carcinoma cell motility and invasion by targeting RhoA. PLoS ONE 2014, 9, e101330. [CrossRef] [PubMed]

244. Xu, Q.; Duan, H.; Gan, L.; Liu, X.; Chen, F.; Shen, X.; Tang, Y.Q.; Wang, S. MicroRNA-1291 promotes endometrial fibrosis by regulating the ArhGAP29-RhoA/ROCK1 signaling pathway in a murine model. Mol. Med. Rep. 2017, 16, 4501-4510. [CrossRef] [PubMed]

245. Zhang, L.; Sun, J.; Wang, B.; Ren, J.C.; Su, W.; Zhang, T. MicroRNA-10b Triggers the Epithelial-Mesenchymal Transition (EMT) of Laryngeal Carcinoma Hep-2 Cells by Directly Targeting the E-cadherin. Appl. Biochem. Biotechnol. 2015, 176, 33-44. [CrossRef] [PubMed]

246. Chung, Y.H.; Li, S.C.; Kao, Y.H.; Luo, H.L.; Cheng, Y.T.; Lin, P.R.; Tai, M.H.; Chiang, P.H. MiR-30a-5p Inhibits Epithelial-to-Mesenchymal Transition and Upregulates Expression of Tight Junction Protein Claudin-5 in Human Upper Tract Urothelial Carcinoma Cells. Int. J. Mol. Sci. 2017, 18, 1826. [CrossRef] [PubMed]

247. Zhang, G.J.; Xiao, H.X.; Tian, H.P.; Liu, Z.L.; Xia, S.S.; Zhou, T. Upregulation of microRNA-155 promotes the migration and invasion of colorectal cancer cells through the regulation of claudin-1 expression. Int. J. Mol. Med. 2013, 31, 1375-1380. [CrossRef] [PubMed]

248. Xiao, L.; Zhou, X.; Liu, F.; Hu, C.; Zhu, X.; Luo, Y.; Wang, M.; Xu, X.; Yang, S.; Kanwar, Y.S.; et al. MicroRNA-129-5p modulates epithelial-to-mesenchymal transition by targeting SIP1 and SOX4 during peritoneal dialysis. Lab. Investig. 2015, 95, 817-832. [CrossRef] [PubMed] 
249. Liu, F.; Wu, L.; Wang, A.; Xu, Y.; Luo, X.; Liu, X.; Hua, Y.; Zhang, D.; Wu, S.; Lin, T.; et al. MicroRNA-138 attenuates epithelial-to-mesenchymal transition by targeting SOX4 in clear cell renal cell carcinoma. Am. J. Transl. Res. 2017, 9, 3611-3622. [PubMed]

250. Pang, L.; Li, B.; Zheng, B.; Niu, L.; Ge, L. miR-138 inhibits gastric cancer growth by suppressing SOX4. Oncol. Rep. 2017, 38, 1295-1302. [CrossRef] [PubMed]

251. Xiong, J.; Wang, D.; Wei, A.; Lu, H.; Tan, C.; Li, A.; Tang, J.; Wang, Y.; He, S.; Liu, X.; et al. Deregulated expression of miR-107 inhibits metastasis of PDAC through inhibition PI3K/Akt signaling via caveolin-1 and PTEN. Exp. Cell Res. 2017, 361, 316-323. [CrossRef] [PubMed]

252. Lv, J.W.; Wen, W.; Jiang, C.; Fu, Q.B.; Gu, Y.J.; Lv, T.T.; Li, Z.D.; Xue, W. Inhibition of microRNA-214 promotes epithelial-mesenchymal transition process and induce interstitial cystitis in postmenopausal women by upregulating Mfn2. Exp. Mol. Med. 2017, 49, e357. [CrossRef] [PubMed]

253. Liu, M.X.; Zhou, K.C.; Cao, Y. MCRS1 overexpression, which is specifically inhibited by miR-129*, promotes the epithelial-mesenchymal transition and metastasis in non-small cell lung cancer. Mol. Cancer. 2014, 13, 245. [CrossRef] [PubMed]

254. Sun, Z.; Han, Q.; Zhou, N.; Wang, S.; Lu, S.; Bai, C.; Zhao, R.C. MicroRNA-9 enhances migration and invasion through KLF17 in hepatocellular carcinoma. Mol. Oncol. 2013, 7, 884-894. [CrossRef] [PubMed]

255. Lu, Y.; Xiao, L.; Liu, Y.; Wang, H.; Li, H.; Zhou, Q.; Pan, J.; Lei, B.; Huang, A.; Qi, S. MIR517C inhibits autophagy and the epithelial-to-mesenchymal (-like) transition phenotype in human glioblastoma through KPNA2-dependent disruption of TP53 nuclear translocation. Autophagy 2015, 11, 2213-2232. [CrossRef] [PubMed]

256. Yang, L.; Fan, Y.; Zhang, X.; Ma, J. miRNA-23 regulates high glucose induced epithelial to mesenchymal transition in human mesothelial peritoneal cells by targeting VDR. Exp. Cell Res. 2017, 360, 375-383. [CrossRef] [PubMed]

257. Pan, J.; Zhang, J.; Zhang, X.; Zhou, X.; Lu, S.; Huang, X.; Shao, J.; Lou, G.; Yang, D.; Geng, Y.J. Role of microRNA-29b in angiotensin II-induced epithelial-mesenchymal transition in renal tubular epithelial cells. Int. J. Mol. Med. 2014, 34, 1381-1387. [CrossRef] [PubMed]

258. Li, W.; Miao, X.; Liu, L.; Zhang, Y.; Jin, X.; Luo, X.; Gao, H.; Deng, X. Methylation-mediated silencing of microRNA-211 promotes cell growth and epithelial to mesenchymal transition through activation of the Akt/ $\beta$-catenin pathway in GBM. Oncotarget 2017, 8, 25167-25176. [CrossRef] [PubMed]

259. Yu, H.; Yang, W. MiR-211 is epigenetically regulated by DNMT1 mediated methylation and inhibits EMT of melanoma cells by targeting RAB22A. Biochem. Biophys. Res. Commun. 2016, 476, 400-405. [CrossRef] [PubMed]

260. Cui, S.; Zhang, K.; Li, C.; Chen, J.; Pan, Y.; Feng, B.; Lu, L.; Zhu, Z.; Wang, R.; Chen, L. Methylation-associated silencing of microRNA-129-3p promotes epithelial-mesenchymal transition, invasion and metastasis of hepatocellular cancer by targeting Aurora-A. Oncotarget 2016, 7, 78009-78028. [CrossRef] [PubMed]

261. Dong, P.; Ihira, K.; Xiong, Y.; Watari, H.; Hanley, S.J.; Yamada, T.; Hosaka, M.; Kudo, M.; Yue, J.; Sakuragi, N. Reactivation of epigenetically silenced miR-124 reverses the epithelial-to-mesenchymal transition and inhibits invasion in endometrial cancer cells via the direct repression of IQGAP1 expression. Oncotarget 2016, 7, 20260-20270. [CrossRef] [PubMed]

262. Pieraccioli, M.; Imbastari, F.; Antonov, A.; Melino, G.; Raschellà, G. Activation of miR200 by c-Myb depends on ZEB1 expression and miR200 promoter methylation. Cell Cycle 2013, 12, 2309-2320. [CrossRef] [PubMed]

263. Taube, J.H.; Malouf, G.G.; Lu, E.; Sphyris, N.; Vijay, V.; Ramachandran, P.P.; Ueno, K.R.; Gaur, S.; Nicoloso, M.S.; Rossi, S.; et al. Epigenetic silencing of microRNA-203 is required for EMT and cancer stem cell properties. Sci. Rep. 2013, 3, 2687. [CrossRef] [PubMed]

264. Yu, Q.; Xiang, L.; Yin, L.; Liu, X.; Yang, D.; Zhou, J. Loss-of-function of miR-142 by hypermethylation promotes TGF- $\beta$-mediated tumour growth and metastasis in hepatocellular carcinoma. Cell Prolif. 2017, 50, e12384. [CrossRef] [PubMed]

265. Liu, C.; Lv, D.; Li, M.; Zhang, X.; Sun, G.; Bai, Y.; Chang, D. Hypermethylation of miRNA-589 promoter leads to upregulation of HDAC5 which promotes malignancy in non-small cell lung cancer. Int. J. Oncol. 2017, 50, 2079-2090. [CrossRef] [PubMed]

266. Yu, F.; Lu, Z.; Chen, B.; Wu, X.; Dong, P.; Zheng, J. Salvianolic acid B-induced microRNA-152 inhibits liver fibrosis by attenuating DNMT1-mediated Patched1 methylation. J. Cell Mol. Med. 2015, 19, 2617-2632. [CrossRef] [PubMed] 
267. Zhang, P.P.; Wang, X.L.; Zhao, W.; Qi, B.; Yang, Q.; Wan, H.Y.; Shuang, Z.Y.; Liu, M.; Li, X.; Li, S.; et al. DNA methylation-mediated repression of miR-941 enhances lysine (K)-specific demethylase 6B expression in hepatoma cells. J. Biol. Chem. 2014, 289, 24724-24735. [CrossRef] [PubMed]

268. Zare, M.; Bastami, M.; Solali, S.; Alivand, M.R. Aberrant miRNA promoter methylation and EMT-involving miRNAs in breast cancer metastasis: Diagnosis and therapeutic implications. J. Cell. Physiol. 2018, 233, 3729-3744. [CrossRef] [PubMed]

269. Träger, M.M.; Dhayat, S.A. Epigenetics of epithelial-to-mesenchymal transition in pancreatic carcinoma. Int. J. Cancer 2017, 141, 24-32. [CrossRef] [PubMed]

270. Sun, L.; Fang, J. Epigenetic regulation of epithelial-mesenchymal transition. Cell. Mol. Life Sci. 2016, 73, 4493-4515. [CrossRef] [PubMed]

271. Warns, J.A.; Davie, J.R.; Dhasarathy, A. Connecting the dots: Chromatin and alternative splicing in EMT. Biochem. Cell Biol. 2016, 94, 12-25. [CrossRef] [PubMed]

272. Nickel, A.; Stadler, S.C. Role of epigenetic mechanisms in epithelial-to-mesenchymal transition of breast cancer cells. Transl. Res. 2015, 165, 126-142. [CrossRef] [PubMed]

273. Lehmann, U. Aberrant DNA methylation of microRNA genes in human breast cancer-A critical appraisal. Cell Tissue Res. 2014, 356, 657-664. [CrossRef] [PubMed]

274. Cicchini, C.; de Nonno, V.; Battistelli, C.; Cozzolino, A.M.; De Santis Puzzonia, M.; Ciafrè, S.A.; Brocker, C.; Gonzalez, F.J.; Amicone, L.; Tripodi, M. Epigenetic control of EMT/MET dynamics: HNF4 $\alpha$ impacts DNMT3s through miRs-29. Biochim. Biophys. Acta 2015, 1849, 919-929. [CrossRef] [PubMed]

275. Fang, S.; Zhang, L.; Guo, J.; Niu, Y.; Wu, Y.; Li, H.; Zhao, L.; Li, X.; Teng, X.; Sun, X.; et al. NONCODEv5: A comprehensive annotation database for long non-coding RNAs. Nucleic Acids Res. 2017, 46, D308-D314. [CrossRef] [PubMed]

276. Schmitz, S.U.; Grote, P.; Herrmann, B.G. Mechanisms of long noncoding RNA function in development and disease. Cell. Mol. Life Sci. 2016, 73, 2491-2509. [CrossRef] [PubMed]

277. Rosa, A.; Ballarino, M. Long noncoding RNA regulation of pluripotency. Stem Cells Int. 2015, $2016,1797692$. [CrossRef] [PubMed]

278. Wapinski, O.; Chang, H.Y. Long noncoding RNAs and human disease. Trends Cell Biol. 2011, $21,354-361$. [CrossRef] [PubMed]

279. Rackham, O.; Shearwood, A.M.J.; Mercer, T.R.; Davies, S.M.; Mattick, J.S.; Filipovska, A. Long noncoding RNAs are generated from the mitochondrial genome and regulated by nuclear-encoded proteins. RNA 2011, 17, 2085-2093. [CrossRef] [PubMed]

280. Li, P.; Zhang, X.; Wang, H.; Wang, L.; Liu, T.; Du, L.; Yang, Y.; Wang, C. MALAT1 Is Associated with Poor Response to Oxaliplatin-Based Chemotherapy in Colorectal Cancer Patients and Promotes Chemoresistance through EZH2. Mol. Cancer Ther. 2017, 16, 739-751. [CrossRef] [PubMed]

281. Berrondo, C.; Flax, J.; Kucherov, V.; Siebert, A.; Osinski, T.; Rosenberg, A.; Fucile, C.; Richheimer, S.; Beckham, C.J. Expression of the Long Non-Coding RNA HOTAIR Correlates with Disease Progression in Bladder Cancer and Is Contained in Bladder Cancer Patient Urinary Exosomes. PLoS ONE 2016, 11, e0147236. [CrossRef] [PubMed]

282. Saito, T.; Kurashige, J.; Nambara, S.; Komatsu, H.; Hirata, H.; Ueda, M.; Sakimura, S.; Uchi, R.; Takano, Y.; Shinden, Y.; et al. A Long Non-coding RNA Activated by Transforming Growth Factor- $\beta$ is an Independent Prognostic Marker of Gastric Cancer. Ann. Surg. Oncol. 2015, 22, S915-S922. [CrossRef] [PubMed]

283. Chen, D.L.; Chen, L.Z.; Lu, Y.X.; Zhang, D.S.; Zeng, Z.L.; Pan, Z.Z.; Huang, P.; Wang, F.H.; Li, Y.H.; Ju, H.Q.; et al. Long noncoding RNA XIST expedites metastasis and modulates epithelial-mesenchymal transition in colorectal cancer. Cell Death Dis. 2017, 8, e3011. [CrossRef] [PubMed]

284. Grelet, S.; Link, L.A.; Howley, B.; Obellianne, C.; Palanisamy, V.; Gangaraju, V.K.; Diehl, J.A.; Howe, P.H. A regulated PNUTS mRNA to lncRNA splice switch mediates EMT and tumour progression. Nat. Cell Biol. 2017, 19, 1105-1115. [CrossRef] [PubMed]

285. Song, Y.X.; Sun, J.X.; Zhao, J.H.; Yang, Y.C.; Shi, J.X.; Wu, Z.H.; Chen, X.W.; Gao, P.; Miao, Z.F.; Wang, Z.N. Non-coding RNAs participate in the regulatory network of CLDN4 via ceRNA mediated miRNA evasion. Nat. Commun. 2017, 8, 289. [CrossRef] [PubMed]

286. Cao, Y.; Shi, H.; Ren, F.; Jia, Y.; Zhang, R. Long non-coding RNA CCAT1 promotes metastasis and poor prognosis in epithelial ovarian cancer. Exp. Cell Res. 2017, 359, 185-194. [CrossRef] [PubMed] 
287. $\mathrm{Xu}$, F.; Zhang, J. Long non-coding RNA HOTAIR functions as miRNA sponge to promote the epithelial to mesenchymal transition in esophageal cancer. Biomed. Pharmacother. 2017, 90, 888-896. [CrossRef] [PubMed]

288. Gulei, D.; Mehterov, N.; Ling, H.; Stanta, G.; Braicu, C.; Berindan-Neagoe, I. The "good-cop bad-cop" TGF- $\beta$ role in breast cancer modulated by non-coding RNAs. Biochim. Biophys. Acta 2017, 1861, 1661-1675. [CrossRef] [PubMed]

289. Cao, M.X.; Jiang, Y.P.; Tang, Y.L.; Liang, X.H. The crosstalk between lncRNA and microRNA in cancer metastasis: Orchestrating the epithelial-mesenchymal plasticity. Oncotarget 2017, 8, 12472-12483. [CrossRef] [PubMed]

290. Terashima, M.; Tange, S.; Ishimura, A.; Suzuki, T. MEG3 Long Noncoding RNA Contributes to the Epigenetic Regulation of Epithelial-Mesenchymal Transition in Lung Cancer Cell Lines. J. Biol. Chem. 2017, 292, 82-99. [CrossRef] [PubMed]

291. Hou, P.; Zhao, Y.; Li, Z.; Yao, R.; Ma, M.; Gao, Y.; Zhao, L.; Zhang, Y.; Huang, B.; Lu, J. LincRNA-ROR induces epithelial-to-mesenchymal transition and contributes to breast cancer tumorigenesis and metastasis. Cell Death Dis. 2014, 5, e1287. [CrossRef] [PubMed]

292. Matouk, I.J.; Raveh, E.; Abu-lail, R.; Mezan, S.; Gilon, M.; Gershtain, E.; Birman, T.; Gallula, J.; Schneider, T.; Barkali, M.; et al. Oncofetal H19 RNA promotes tumor metastasis. Biochim. Biophys. Acta 2014, 1843, 1414-1426. [CrossRef] [PubMed]

293. Xiang, Y.; Zhang, Y.; Tang, Y.; Li, Q. MALAT1 Modulates TGF- $\beta 1$-Induced Endothelial-to-Mesenchymal Transition through Downregulation of miR-145. Cell. Physiol. Biochem. 2017, 42, 357-372. [CrossRef] [PubMed]

294. Yuan, J.H.; Yang, F.; Wang, F.; Ma, J.Z.; Guo, Y.J.; Tao, Q.F.; Liu, F.; Pan, W.; Wang, T.T.; Zhou, C.C.; et al. A long noncoding RNA activated b TGF- $\beta$ promotes the invasion-metastasis cascade in hepatocellular carcinoma. Cancer Cell 2014, 25, 666-681. [CrossRef] [PubMed]

295. Jiang, Z.; Jiang, C.; Fang, J. Up-regulated lnc-SNHG1 contributes to osteosarcoma progression through sequestration of miR-577 and activation of WNT2B/Wnt/ $\beta$-catenin pathway. Biochem. Biophys. Res. Commun. 2018, 495, 238-245. [CrossRef] [PubMed]

296. Xiao, J.N.; Yan, T.H.; Yu, R.M.; Gao, Y.; Zeng, W.L.; Lu, S.W.; Que, H.X.; Liu, Z.P.; Jiang, J.H. Long non-coding RNA UCA1 regulates the expression of Snail2 by miR-203 to promote hepatocellular carcinoma progression. J. Cancer Res. Clin. Oncol. 2017, 143, 981-990. [CrossRef] [PubMed]

297. Chang, Z.; Cui, J.; Song, Y. Long noncoding RNA PVT1 promotes EMT via mediating microRNA-186 targeting of Twist1 in prostate cancer. Gene 2018, 654, 36-42. [CrossRef] [PubMed]

298. Tao, Y.; Han, T.; Zhang, T.; Ma, C.; Sun, C. LncRNA CHRF-induced miR-489 loss promotes metastasis of colorectal cancer via TWIST1/EMT signaling pathway. Oncotarget 2017, 8, 36410-36422. [CrossRef] [PubMed]

299. Zhang, K.; Chen, J.; Song, H.; Chen, L.B. SNHG16/miR-140-5p axis promotes esophagus cancer cell proliferation, migration and EMT formation through regulating ZEB1. Oncotarget 2017, 9, 1028-1040. [CrossRef] [PubMed]

300. Lu, Y.; Li, T.; Wei, G.; Liu, L.; Chen, Q.; Xu, L.; Zhang, K.; Zeng, D.; Liao, R. The long non-coding RNA NEAT1 regulates epithelial to mesenchymal transition and radioresistance in through miR-204/ZEB1 axis in nasopharyngeal carcinoma. Tumour Biol. 2016, 37, 11733-11741. [CrossRef] [PubMed]

301. Li, S.P.; Xu, H.X.; Yu, Y.; He, J.D.; Wang, Z.; Xu, Y.J.; Wang, C.Y.; Zhang, H.M.; Zhang, R.X.; Zhang, J.J.; et al. LncRNA HULC enhances epithelial-mesenchymal transition to promote tumorigenesis and metastasis of hepatocellular carcinoma via the miR-200a-3p/ZEB1 signaling pathway. Oncotarget 2016, 7, 42431-42446. [CrossRef] [PubMed]

302. Zhu, H.; Zeng, Y.; Zhou, C.C.; Ye, W. SNHG16/miR-216-5p/ZEB1 signal pathway contributes to the tumorigenesis of cervical cancer cells. Arch. Biochem. Biophys. 2018, 637, 1-8. [CrossRef] [PubMed]

303. Chen, D.L.; Lu, Y.X.; Zhang, J.X.; Wei, X.L.; Wang, F.; Zeng, Z.L.; Pan, Z.Z.; Yuan, Y.F.; Wang, F.H.; Pelicano, H.; et al. Long non-coding RNA UICLM promotes colorectal cancer liver metastasis by acting as a ceRNA for microRNA-215 to regulate ZEB2 expression. Theranostics 2017, 7, 4836-4849. [CrossRef] [PubMed]

304. Tan, J.; Qiu, K.; Li, M.; Liang, Y. Double-negative feedback loop between long non-coding RNA TUG1 and miR-145 promotes epithelial to mesenchymal transition and radioresistance in human bladder cancer cells. FEBS Lett. 2015, 589, 3175-3181. [CrossRef] [PubMed] 
305. Zhou, X.; Ye, F.; Yin, C.; Zhuang, Y.; Yue, G.; Zhang, G. The Interaction Between MiR-141 and lncRNA-H19 in Regulating Cell Proliferation and Migration in Gastric Cancer. Cell. Physiol. Biochem. 2015, 36, 1440-1452. [CrossRef] [PubMed]

306. Kong, Q.; Qiu, M. Long noncoding RNA SNHG15 promotes human breast cancer proliferation, migration and invasion by sponging miR-211-3p. Biochem. Biophys. Res. Commun. 2018, 495, 1594-1600. [CrossRef] [PubMed]

307. Zhang, S.; Xiao, J.; Chai, Y.; Du, Y.Y.; Liu, Z.; Huang, K.; Zhou, X.; Zhou, W. LncRNA-CCAT1 Promotes Migration, Invasion, and EMT in Intrahepatic Cholangiocarcinoma Through Suppressing miR-152. Dig. Dis. Sci. 2017, 62, 3050-3058. [CrossRef] [PubMed]

308. Zhao, L.; Sun, H.; Kong, H.; Chen, Z.; Chen, B.; Zhou, M. The LncRNA-TUG1/EZH2 Axis Promotes Pancreatic Cancer Cell Proliferation, Migration and EMT Phenotype Formation Through Sponging MiR-382. Cell. Physiol. Biochem. 2017, 42, 2145-2158. [CrossRef] [PubMed]

309. Lv, M.; Zhong, Z.; Huang, M.; Tian, Q.; Jiang, R.; Chen, J. LncRNA H19 regulates epithelial-mesenchymal transition and metastasis of bladder cancer by miR-29b-3p as competing endogenous RNA. Biochim. Biophys. Acta 2017, 1864, 1887-1899. [CrossRef] [PubMed]

310. Li, Q.; Zhang, C.; Chen, R.; Xiong, H.; Qiu, F.; Liu, S.; Zhang, M.; Wang, F.; Wang, Y.; Zhou, X.; et al. Disrupting MALAT1/miR-200c sponge decreases invasion and migration in endometrioid endometrial carcinoma. Cancer Lett. 2016, 383, 28-40. [CrossRef] [PubMed]

311. Lv, J.; Fan, H.X.; Zhao, X.P.; Lv, P.; Fan, J.Y.; Zhang, Y.; Liu, M.; Tang, H. Long non-coding RNA Unigene56159 promotes epithelial-mesenchymal transition by acting as a ceRNA of miR-140-5p in hepatocellular carcinoma cells. Cancer Lett. 2016, 382, 166-175. [CrossRef] [PubMed]

312. Wang, Y.; Liu, Z.; Yao, B.; Dou, C.; Xu, M.; Xue, Y.; Ding, L.; Jia, Y.; Zhang, H.; Li, Q.; et al. Long non-coding RNA TUSC7 acts a molecular sponge for miR-10a and suppresses EMT in hepatocellular carcinoma. Tumour Biol. 2016, 37, 11429-11441. [CrossRef] [PubMed]

313. Liang, W.C.; Fu, W.M.; Wong, C.W.; Wang, Y.; Wang, W.M.; Hu, G.X.; Zhang, L.; Xiao, L.J.; Wan, D.C.; Zhang, J.F.; et al. The lncRNA H19 promotes epithelial to mesenchymal transition by functioning as miRNA sponges in colorectal cancer. Oncotarget 2015, 6, 22513-22525. [CrossRef] [PubMed]

314. Wang, Y.; Liu, Z.; Yao, B.; Li, Q.; Wang, L.; Wang, C.; Dou, C.; Xu, M.; Liu, Q.; Tu, K. Long non-coding RNA CASC2 suppresses epithelial-mesenchymal transition of hepatocellular carcinoma cells through CASC2/miR-367/FBXW7 axis. Mol. Cancer 2017, 16, 123. [CrossRef] [PubMed]

315. Ye, K.; Wang, S.; Zhang, H.; Han, H.; Ma, B.; Nan, W. Long Noncoding RNA GAS5 Suppresses Cell Growth and Epithelial-Mesenchymal Transition in Osteosarcoma by Regulating the miR-221/ARHI Pathway. J. Cell. Biochem. 2017, 118, 4772-4781. [CrossRef] [PubMed]

316. Hong, Q.; Li, O.; Zheng, W.; Xiao, W.Z.; Zhang, L.; Wu, D.; Cai, G.Y.; He, J.C.; Chen, X.M. LncRNA HOTAIR regulates HIF-1 $\alpha /$ AXL signaling through inhibition of miR-217 in renal cell carcinoma. Cell Death Dis. 2017, 8, e2772. [CrossRef] [PubMed]

317. Ma, F.; Wang, S.H.; Cai, Q.; Jin, L.Y.; Zhou, D.; Ding, J.; Quan, Z.W. Long non-coding RNA TUG1 promotes cell proliferation and metastasis by negatively regulating miR-300 in gallbladder carcinoma. Biomed. Pharmacother. 2017, 88, 863-869. [CrossRef] [PubMed]

318. Cai, Q.; Wang, Z.; Wang, S.; Weng, M.; Zhou, D.; Li, C.; Wang, J.; Chen, E.; Quan, Z. Long non-coding RNA LINC00152 promotes gallbladder cancer metastasis and epithelial-mesenchymal transition by regulating HIF-1 $\alpha$ via miR-138. Open Biol. 2017, 7, 160247. [CrossRef] [PubMed]

319. Zhang, H.Y.; Liang, F.; Zhang, J.W.; Wang, F.; Wang, L.; Kang, X.G. Effects of long noncoding RNA-ROR on tamoxifen resistance of breast cancer cells by regulating microRNA-205. Cancer Chemother. Pharmacol. 2017, 79, 327-337. [CrossRef] [PubMed]

320. Lu, L.; Luo, F.; Liu, Y.; Liu, X.; Shi, L.; Lu, X.; Liu, Q. Posttranscriptional silencing of the lncRNA MALAT1 by miR-217 inhibits the epithelial-mesenchymal transition via enhancer of zeste homolog 2 in the malignant transformation of HBE cells induced by cigarette smoke extract. Toxicol. Appl. Pharmacol. 2015, 289, 276-285. [CrossRef] [PubMed]

321. Liu, Y.W.; Sun, M.; Xia, R.; Zhang, E.B.; Liu, X.H.; Zhang, Z.H.; Xu, T.P.; De, W.; Liu, B.R.; Wang, Z.X. LincHOTAIR epigenetically silences miR34a by binding to PRC2 to promote the epithelial-to-mesenchymal transition in human gastric cancer. Cell Death Dis. 2015, 6, e1802. [CrossRef] [PubMed] 
322. Ye, P.; Wang, T.; Liu, W.H.; Li, X.C.; Tang, L.J.; Tian, F.Z. Enhancing HOTAIR/MiR-10b Drives Normal Liver Stem Cells Toward a Tendency to Malignant Transformation Through Inducing Epithelial-to-Mesenchymal Transition. Rejuvenation Res. 2015, 18, 332-340. [CrossRef] [PubMed]

323. Li, J.T.; Wang, L.F.; Zhao, Y.L.; Yang, T.; Li, W.; Zhao, J.; Yu, F.; Wang, L.; Meng, Y.L.; Liu, N.N.; et al. Nuclear factor of activated $\mathrm{T}$ cells 5 maintained by HOTAIR suppression of miR-568 upregulates $\mathrm{S} 100$ calcium binding protein A4 to promote breast cancer metastasis. Breast Cancer Res. 2014, 16, 454. [CrossRef] [PubMed]

324. Zhang, H.; Cai, K.; Wang, J.; Wang, X.; Cheng, K.; Shi, F.; Jiang, L.; Zhang, Y.; Dou, J. MiR-7, inhibited indirectly by lincRNA HOTAIR, directly inhibits SETDB1 and reverses the EMT of breast cancer stem cells by downregulating the STAT3 pathway. Stem Cells 2014, 32, 2858-2868. [CrossRef] [PubMed]

325. Ma, C.; Nong, K.; Zhu, H.; Wang, W.; Huang, X.; Yuan, Z.; Ai, K. H19 promotes pancreatic cancer metastasis by derepressing let-7's suppression on its target HMGA2-mediated EMT. Tumour Biol. 2014, 35, 9163-9169. [CrossRef] [PubMed]

(C) 2018 by the authors. Licensee MDPI, Basel, Switzerland. This article is an open access article distributed under the terms and conditions of the Creative Commons Attribution (CC BY) license (http://creativecommons.org/licenses/by/4.0/). 